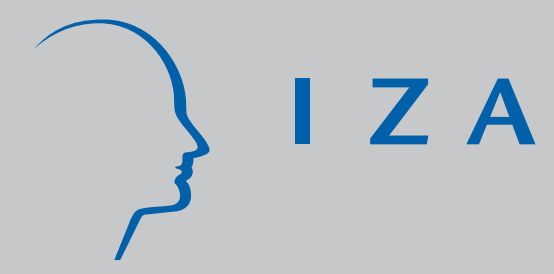

IZADP No. 2235

Earnings Inequality and Market Work in Husband-Wife Families

John Pencavel

July 2006 


\title{
Earnings Inequality and Market Work in Husband-Wife Families
}

\author{
John Pencavel \\ Stanford University \\ and IZA Bonn
}

\author{
Discussion Paper No. 2235 \\ July 2006
}

\author{
IZA \\ P.O. Box 7240 \\ 53072 Bonn \\ Germany \\ Phone: $+49-228-3894-0$ \\ Fax: +49-228-3894-180 \\ Email: iza@iza.org
}

\begin{abstract}
Any opinions expressed here are those of the author(s) and not those of the institute. Research disseminated by IZA may include views on policy, but the institute itself takes no institutional policy positions.
\end{abstract}

The Institute for the Study of Labor (IZA) in Bonn is a local and virtual international research center and a place of communication between science, politics and business. IZA is an independent nonprofit company supported by Deutsche Post World Net. The center is associated with the University of Bonn and offers a stimulating research environment through its research networks, research support, and visitors and doctoral programs. IZA engages in (i) original and internationally competitive research in all fields of labor economics, (ii) development of policy concepts, and (iii) dissemination of research results and concepts to the interested public.

IZA Discussion Papers often represent preliminary work and are circulated to encourage discussion. Citation of such a paper should account for its provisional character. A revised version may be available directly from the author. 
IZA Discussion Paper No. 2235

July 2006

\section{ABSTRACT \\ Earnings Inequality and Market Work in Husband-Wife Families}

Constructing pseudo-panel data from successive Current Population Surveys, this paper analyzes earnings inequality in husband and wife families over the life cycle and over time. Particular attention is devoted to the role of labor supply in influencing measures of earnings inequality. Compact and accurate descriptions of earnings inequality are derived that facilitate the analysis of the effect of the changing market employment of wives on earnings inequality. The growing propensity of married women to work for pay has mitigated the increase in family earnings inequality. Alternative measures of earnings inequality covering people with different degrees of attachment to the labor market are constructed. Inferences about the extent and changes in earnings inequality are sensitive to alternative labor supply definitions especially in the case of wives.

JEL Classification: J31, J22, D63

Keywords: earnings inequality, married women's employment-population ratios, hours of work

Corresponding author:

John Pencavel

Department of Economics

Stanford University

Stanford, CA 94305-6072

USA

E-mail: pencavel@stanford.edu 


\title{
EARNINGS INEQUALITY AND MARKET WORK IN HUSBAND-WIFE FAMILIES
}

\author{
John Pencavel ${ }^{*}$
}

\section{Introduction}

To what extent do the increases in earnings inequality among individual American workers pose an issue for public policy? To answer this, we would want to know the extent to which changes in individual earnings translate into changes in income inequality in the households within which these earnings are pooled and shared. The link between the earnings of one household member and the income consumed of each household member depends not only on the magnitude of this individual's earnings but on whether other household members work for pay, and, if so, how many hours they work, on other sources of income, and on changing patterns of household formation and dissolution. Hence the connection between the growth in inequality of individual pay and changes in income consumed by individuals (both those who work for pay and those who do not) is complex and involves a number of interrelated factors.

Some of these links are traced out in this paper which focuses on income in husbandwife families. First, we determine the extent to which changes in income inequality are attributable to changes in inequality in labor market earnings. Second, we examine changes in family earnings inequality and assess how increases in wives' employment have affected family earnings inequality. To address this, a simple and compact accounting framework is derived that describes the movements of family earnings inequality and that may be used to discriminate between the part played by husbands' earnings and that played by married women's employment in understanding movements in family earnings inequality.

\footnotetext{
* This paper benefitted from Alan Krueger's and Rob Valletta's comments on a previous draft and from the criticism of two anonymous referees. I am indebted to Niny Khor for her scrupulous research assistance. Support from the Smith-Richardson Foundation is gratefully acknowledged.
} 
We then turn to earnings inequality of wives and husbands separately and ascertain how changes in earnings inequality are affected by differences in the degree to which the husbands and wives work in the labor market. Again, a simple expression is derived that links earnings inequality to the employment-population ratio. This inspires the more general question: are inferences about differences and changes in earnings inequality sensitive to variations among people in their commitment to market work? Imagine the population being censored in increasing degrees by the extent of their market work: have the changes in earnings inequality for these groups in the population been the same?

In addressing these questions, the analysis will recognize that income inequality varies over the lifetime: husband-wife incomes are more unequal among older couples than among younger couples. Furthermore, the past thirty years has seen an aging of the typical husband-wife couple induced in part by the postponement of age of first marriage. In 1967-69, in almost fourteen percent of all couples, the wives were aged between 20 and 25 years; by 1998-2000, only 5.4 percent were in this category. In 1998-2000, there were almost ten percent more couples with wives aged above 36 years than there were in 1967-69. By organizing the data by years since leaving school, we differentiate between two time effects on income inequality: the increase in income inequality associated with the aging of a household and the increase in income inequality that has occurred over time even among households of the same age. ${ }^{1}$

\footnotetext{
${ }^{1}$ Previous research tends to place a heavier emphasis on cross-section data to draw inferences about the effects of the growth of market employment of wives on family earnings inequality. See, for instance, the recent careful research of Daly and Valletta (2006) who reach conclusions fully compatible with those in this paper. Earlier work includes that of Smith (1979) using the 1960 and 1970 Censuses of Population and Lehrer and Nerlove (1981) who use data from the National Survey of Family Growth. Cancian, Danziger, and Gottschalk (1993) draw on March CPS data from 1968 to 1988. Cancian and Reed (1998) argue that the distribution of family income in 1979 and 1989 would have shown greater dispersion without the earnings of wives. A similar conclusion was reached by Gronau (1982) for Israel. Hyslop’s (2001) research is confined to husbands and wives
} 
At the outset, some important restrictions on the analysis need to be noted. First, the data used in this paper are drawn from successive March Current Population Surveys and they do not constitute genuine panel data which can record changes in the marital status of a given population. On the other hand, panel data have serious problems of non-random attrition with changes in marital status constituting one of the key reasons for losing individuals from the panel survey. The CPS allows the construction of pseudo-panels and, as the principal source of information about the U.S. labor force, the CPS provides a large and accurate characterization of the U.S. population.

Second, over the past thirty years or so, the number and attributes of married people have changed: many fewer adults are now married with spouse present and those who are married tend to be better schooled and older (relative to unmarried people) than they were in the 1960s. So married people at the end of our period are a more select group of the adult population.

Third, this paper focuses on incomes generated by the market so government taxes and transfers will be ignored. Of course, the presence of such taxes and transfers may well affect the level and structure of market incomes but this is neglected here. At the same time, the movement of pre-tax household income has followed closely the movement of post-tax household income even though there have been non-negligible changes in the tax structure as in the Tax Reform Act of 1986 and the reform of the welfare system in the 1990 s. $^{2}$

We turn first to a description of the data and the methods underlying this research.

\section{Construction of the Data}

There are different ways of examining the evolution of people's earnings over time.

both of whom work for pay and he covers the six years from 1979 to 1985.

${ }^{2}$ See Congressional Budget Office (2005). 
In a companion paper (Pencavel (2006)), husband and wife couples are organized by their year of birth and by their age. ${ }^{3}$ In this paper, people are "born” when they have completed their schooling so each cohort is defined as the calendar year in which the cohort members left school and could have started their market work careers. Their "age” is measured by the years that have elapsed since schooling completion. Years since completion of schooling is called "experience”. ${ }^{4}$

When a husband and wife are born in the same year and complete the same schooling, the couple's cohort and experience are the same whether defined by the husband's characteristics or the wife's. However, when the wife's year of birth and schooling differ from the husband's, their cohort and experience may not be the same. Because cross-classifying husbands and wives by the cohort and experience of each individual consumes many degrees of freedom, we define cohorts by five year intervals so that some couples of the same age would have to have large differences in schooling not to be in the same cohort and we index a family's "experience” by the years since the wife has left school. We organize the family's data by the wife's experience and cohort because the relationship between the employment and earnings of wives and family earnings inequality plays a special role in this analysis.

The Annual Demographic Supplements of the March Current Population Surveys for 1968 through to 2001are used to sort husband and wife couples into cohorts defined by the estimated year of schooling completion and by the years of experience of the wife. Each cohort covers a five

\footnotetext{
${ }^{3}$ This companion paper uses a different decomposition of family earnings inequality from the one used here and it does not take up the issue of the extent to which inferences about changes in earnings inequality for wives and husbands separately are affected by differences in market work behavior.

${ }^{4}$ In the research reported in this paper, experience is defined as the minimum of (1) current age minus years of schooling minus six and (2) age minus seventeen. Other definitions were investigated for earlier cohorts with minimal consequences for the empirical regularities reported here.
} 
year interval from 1926-30 to 1991-95. Table 1 lists the resulting 294 cohort-experience cells we use. Each cell consists of no less than one thousand husband-wife pairs.

Three components of family income are distinguished: the husband's earnings; the wife's earnings; and the interest, dividends, and rent received by the husband and wife. These components are measured before tax and transfers - the purpose is to examine the differences across families in the incomes generated by the market, not by the adjustments that governments make to these incomes - and they neglect the incomes of any other family members. For any experience $x$ and cohort $c$ cell, let $y_{H i}(x, c)$ denote the annual earnings of the husband in household $i, y_{W i}(x, c)$ the annual earnings of the wife in household $i$, and $y_{N i}(x, c)$ the annual nonlabor income (the sum of dividends, interest, and rent) of household $i .^{5}$ To be included, both husband and wife must be at least 20 years of age and not more than 60 years. To avoid the difficulties in measuring the labor returns to people who are self-employed, couples containing a self-employed worker are excluded.

For most husband-wife families, labor market earnings constitute the most important components of income and nonlabor income represents a relatively small part. Across these 294 cells, the average of the ratio of nonlabor income to total income is 0.045 . Furthermore, for a study of income inequality across all husband-wife families, variations in nonlabor income are not important. This is illustrated in Figure 1 where for two cohorts, cohorts 6 and 9, the Gini coefficients of income inequality are graphed: one Gini coefficient includes nonlabor income (this is marked as "incl N") and the other Gini coefficient excludes nonlabor income (marked as "excl N”). For each cohort, income inequality rises with experience and the more recent cohort, cohort

${ }^{5}$ For a very small number of families, the sum of interest, dividends, and rent is negative. This arises because some report negative rent (i.e, the payment, not the receipt, of rent). In these instances, the sum of dividends, interest, and rent was set to zero. This happens so infrequently that nothing of any consequence follows from this. 
9, exhibits greater income inequality than the earlier cohort, cohort 6 . The values of the Gini coefficient that includes nonlabor income is slightly higher at low years of experience and slightly lower at high years of experience than the values of the Gini coefficient that excludes nonlabor income. However, the movements in the two Gini coefficients are close. Across all 294 experiencecohort cells, the correlation coefficient between the Gini coefficient including nonlabor income and the Gini coefficient excluding nonlabor income is 0.993 . In view of this, we shall simplify our analysis of inequality by neglecting nonlabor income and by concentrating on labor earnings. We shall call the sum of the husband's earnings and the wife's earnings "family" earnings: $y_{i}(x, c)=$ $y_{H i}(x, c)+y_{W i}(x, c){ }^{6}$

\section{An Expression to Describe Movements in Family Earnings Inequality}

The purpose of this section is to derive an expression permitting reliable simulations of the movements of family earnings inequality. This expression is addressed to assessing the extent to which increases in wives' employment have affected family earnings inequality. The equation to be derived takes the following form:

$$
G=\beta_{0}+\beta_{1} G_{H}+\beta_{2} \frac{m_{W} E_{W}}{m_{H} E_{H}}+\beta_{3}\left[\frac{m_{W} E_{W}}{m_{H} E_{H}}\right]^{2}+u
$$

\footnotetext{
${ }^{6}$ To address the changing top-coding of income in the CPS, we use an imputation procedure to generate a measure of earnings for people whose earnings are above the top-coded level. Information on the earnings structure of people just below the top-coded earnings level is used to infer earnings of those people above the top-coded level. The appendix of Pencavel (2006) describes this procedure. In addition, many of the results reported in this paper on income inequality were confirmed for measures that do not use information on the earnings of all people such as ratios of earnings at different percentiles. The principal results in this paper are independent of the particular measure of income inequality used and are not affected by the issue of top-coding. Basically this is because, in most years, only a very small fraction of husband-wife families have their earnings top-coded. Nevertheless, for some measures of inequality in some years, top-coding may have profound effects on inferences about earnings inequality. See Burkhauser et al. (2004).
} 
where $G$ stands for the Gini coefficient of family earnings inequality, $G_{H}$ is the Gini coefficient of husbands' earnings inequality, $E_{H}$ and $E_{W}$ are, respectively, the employment-population ratios of husbands and wives, $m_{H}$ and $m_{W}$ are the mean earnings of husbands and the mean earnings of wives among those husbands and wives employed for pay, and $u$ is a term that incorporates other factors. The $\beta$ 's are parameters to be estimated. This expression is an approximation to an accounting framework. It will be shown that a very large fraction of the variations in family earnings inequality is removed by this linear (in the parameters) approximation and that equation (1) provides a compact means of discriminating between the roles of husbands' earnings inequality and married women's employment to describe the movements in family earnings inequality. We proceed to deriving and rationalizing equation (1).

$$
\text { If } \sigma_{H}(x, c) \text { is the standard deviation of the earnings of husbands, } \sigma_{W}(x, c) \text { the standard }
$$
deviation of the earnings of wives, and $\sigma(x, c)$ the standard deviation of family earnings, then

$$
\sigma^{2}(x, c)={\sigma_{H}}^{2}(x, c)+{\sigma_{W}}^{2}(x, c)+2 r(x, c) \cdot \sigma_{H}(x, c) \cdot \sigma_{W}(x, c)
$$

where $r(x, c)$ is the correlation coefficient between the earnings of the spouses. To reduce needless notation, we drop the cohort, $c$, and experience, $x$, identifiers. Let $V$ denote the coefficient of variation in family earnings (i.e., $V=\sigma / \mu$ where $\mu$ stands for the mean of family earnings) and let $V_{j}$ represent the coefficient of variation in $j$ 's earnings (i.e., $V_{j}=\sigma_{j} / \mu_{j}$ ) where $j=H$, $W$. Then the previous equation may be written

$$
V^{2}=\left(B_{H}\right)^{2} \cdot\left(V_{H}\right)^{2}+\left(B_{W}\right)^{2} \cdot\left(V_{W}\right)^{2}+2 \cdot r \cdot B_{H} \cdot B_{W} \cdot V_{H} \cdot V_{W}
$$

where $B_{H}=\mu_{H} / \mu$ and $B_{W}=\mu_{W} / \mu$. So $B_{H}$ and $B_{W}$ are, respectively, each cell's average values of the shares of the husband's earnings and of the wife's earnings in family earnings. In Section V of this paper, expressions will be derived for $\left(V_{H}\right)^{2}$ and $\left(V_{W}\right)^{2}$ that involve the employment-population ratios of husbands and wives, respectively, but for now we concentrate on family earnings 
inequality, $V^{2}$ in the previous equation.

Descriptive statistics on all elements of equation (2) are contained in Table 2. The values of these variables describe all husband-wife households regardless of their labor market status. People who do not work in the market report zero earnings and such people are included in the statistics in Table 2. Thus the coefficient of variation of wives' earnings, $V_{W}$, is higher than that of husbands', $V_{H}$, principally because the employment-population ratio of wives has been much lower than that of husbands and, therefore, the frequency distribution of wives' earnings has a much higher spike at zero.

Similarly, $r$ measures the correlation coefficient between husbands' earnings and wives’ earnings in each cohort-experience cell among all husbands and wives, not merely among working husbands and working wives. $r$ tends to be higher in recent cohorts principally because, in recent cohorts, the employment-population ratio of wives is much higher than in earlier cohorts. ${ }^{7}$ When the wives' employment-population ratio is low, the relatively large number of zero values for wives' earnings inclines $r$ to be low. As the wives' employment-population ratio rises and more women record positive earnings, so higher values of $r$ are recorded. The frequency distribution of $r$ is graphed in Figure 2. Ninety-two percent per cent of cells have values of $r$ in the range of \pm 0.15 . With such values of $r$, an approximation of equation (2) is

$$
V^{2}=\left(B_{H}\right)^{2} \cdot\left(V_{H}\right)^{2}+\left(B_{W}\right)^{2} \cdot\left(V_{W}\right)^{2} \text {. }
$$

Confirmation that this is a good approximation is provided by values of

$$
H=\operatorname{abs} \cdot\left\{\frac{V^{2}-\left(B_{H}^{2}\right) \cdot\left(V_{H}^{2}\right)-\left(B_{W}^{2}\right) \cdot\left(V_{W}^{2}\right)}{V^{2}}\right\}
$$

\footnotetext{
${ }^{7}$ The simple correlation coefficient between $r$ and the wives' employment-population ratio across these 294 cells is 0.614 . An associated reason for a rising value of $r$ is the growth in assortative mating by skill, that is, the growing propensity for well-educated men and well-educated women to marry. See Pencavel (1998).
} 
where $a b s$ denotes the absolute value of the term in braces. $H$ is simply a rearrangement of equation (2) that neglects the third term on the right-hand side. Low values of $H$ suggest that (3) provides a good approximation to (2). $H$ is graphed for five cohorts in Figure 3. The only cases in which $H$ exceeds 0.15 are for a few cells corresponding to young couples in the most recent cohort. In most cases, $H$ is less than 0.10 . Hence we shall proceed with the approximation given by equation (3). After factoring $\left(B_{H}\right)^{2} .\left(V_{H}\right)^{2}$ and taking logarithms, equation (3) can be rewritten as

$$
\ln V=\ln V_{H}+\ln B_{H}+(0.5) \ln \left[1+\left(B_{W} / B_{H}\right)^{2}\left(V_{W} / V_{H}\right)^{2}\right] \text {. }
$$

The left-hand side of this equation, the logarithm of the coefficient of variation in family earnings, is an indicator of the inequality in family earnings. The broad movements in $\ln V$ are similar to those of the Gini coefficient of family earnings, $G$, as is evident from the smoothed values of $\ln V$ and $G$ shown in Figures 4 and 5. The dispersion of family earnings rises sharply with experience for each cohort: for instance, following the data for the 1956-60 cohort, according to both $\ln V$ and $G$, inequality at 37 years is about twice that observed thirty years earlier. ${ }^{8}$ In addition, each cohort's family earnings inequality tends to lie above the previous cohort's inequality at any experience level: at ten years of experience, the 1986-90 cohort's values of $\ln V$ are 1.5 times and its values of $G$ are 1.3 times those for the cohort entering the labor market thirty years earlier. ${ }^{9}$

Further approximations of equation (4) facilitate a better understanding of changes

${ }^{8}$ For this cohort, $\ln V$ at 8 years is about -0.70 and at 37 years it is about zero so $\ln [V(1956-60$, $37) / \ln V(1956-60,8)]=0.70$ and $\exp (0.70)=2.014$. Similarly, $G$ at 37 years is almost twice that at 7 years.

${ }^{9}$ At ten years of experience, $\ln V$ for the $1986-90$ cohort is -0.141 and for the $1956-60$ cohort it is -0.575 so $\ln [V(1986-90,10) / \ln V(1956-60,10)]=0.434$ and $\exp (0.434)=1.543$. The experience and cohort effects graphed in Figures 4 and 5 are similar to those for another indicator of inequality, namely, the variance of the logarithm of income. The latter is a common measure of inequality among workers. However, the logarithmic transform is less appealing when incomes are zero and when some adjustment to zero incomes is required to make the measure more meaningful. 
in family earnings inequality. First, given $B_{H}=\mu_{H} / \mu$ where $\mu_{H}$ is the mean of husbands' earnings and $\mu$ the mean of family earnings (including those not working for pay), if $m_{H}$ and $m_{W}$ denote, respectively, the mean earnings of husbands and the mean earnings of wives among those husbands and wives employed for pay and if $E_{H}$ and $E_{W}$ denote respectively the employment-population ratios of husbands and wives, then

$$
\ln B_{H}=-\ln \left[1+\left(m_{W} E_{W}\right) /\left(m_{H} E_{H}\right)\right] \doteq-\left(m_{W} E_{W}\right) /\left(m_{H} E_{H}\right) .
$$

The last step is an approximation and to assess the quality of this approximation form

$$
-\ln \left[1+\left(m_{W} \cdot E_{W}\right) /\left(m_{H} E_{H}\right)\right]+\left(m_{W} \cdot E_{W}\right) /\left(m_{H} E_{H}\right),
$$

the frequency distribution of which is given in Figure 6. All values are less than 0.10 and 95 percent are less than 0.06 .

Now consider substituting $\left(B_{W} / B_{H}\right)^{2}\left(V_{W} / V_{H}\right)^{2}$ for $\ln \left[1+\left(B_{W} / B_{H}\right)^{2}\left(V_{W} / V_{H}\right)^{2}\right]$ in equation (4). To evaluate this, compute $\ln \left[1+\left(B_{W} / B_{H}\right)^{2}\left(V_{W} / V_{H}\right)^{2}\right]-\left(B_{W} / B_{H}\right)^{2}\left(V_{W} / V_{H}\right)^{2}$ whose values for all 294 cells are presented by the frequency distribution in Figure 7. Over ninety percent of the cells have values between -0.075 and zero with the mean being -0.032 .

$$
\text { Replacing } \ln \left[1+\left(B_{W} / B_{H}\right)^{2}\left(V_{W} / V_{H}\right)^{2}\right] \text { with }\left(B_{W} / B_{H}\right)^{2}\left(V_{W} / V_{H}\right)^{2} \text { and using }
$$
equation (5), equation (4) may be written approximately as

$$
\ln V=\ln V_{H}-\frac{m_{W} E_{W}}{m_{H} E_{H}}+\frac{1}{2}\left[\frac{m_{W} E_{W}}{m_{H} E_{H}} \cdot \frac{V_{W}}{V_{H}}\right]^{2}
$$

Equation (6) proposes a remarkably simple expression to describe movements in the dispersion of family earnings: approximately, the logarithm of the coefficient of variation of family earnings, $\ln V$, equals the logarithm of the coefficient of variation of husbands' earnings, $\ln V_{H}$, less a quadratic term involving ( $\left.m_{W} E_{W}\right) /\left(m_{H} E_{H}\right)$, the ratio of mean wives' earnings to mean husbands' earnings where these mean earnings are not conditional upon working for pay. The ratio of the coefficient 
of variation of wives' earnings to the coefficient of variation of husbands' earnings, $V_{W} / V_{H}$, also enters this expression, but the next step will involve treating this as parametric. Suppose $\left(V_{W} / V_{H}\right.$ )$^{2}=k$ and, to move to the Gini coefficient as a more familiar indicator of inequality, suppose $\ln V$ $=a_{0}+a_{1} G+u_{1}$ and $\ln V_{H}=b_{0}+b_{1} G_{H}+u_{2},{ }^{10}$ then equation (6) may be written as

$$
G=\beta_{0}+\beta_{1} G_{H}+\beta_{2} \frac{m_{W} E_{W}}{m_{H} E_{H}}+\beta_{3}\left[\frac{m_{W} E_{W}}{m_{H} E_{H}}\right]^{2}+u
$$

where the stochastic term $u$ incorporates the various approximations that have been made and the $\beta$ 's are parameters to be estimated. This is equation (1), the expression introduced at the beginning of this section to describe variations in family earnings inequality in terms of variations in husbands' earnings inequality and in wives' relative employment and pay. Equation (1) treats $\left(V_{W} / V_{H}\right)^{2}$ as parametric and incorporates it into the term $\beta_{3}$. Of course, $\left(V_{W} / V_{H}\right)^{2}$ is not fixed so the question is whether this assumption impedes an attempt to derive a useful compact description of the main empirical regularities in family earnings inequality.

The intuition behind equation (1) is that the inequality of family earnings will equal the inequality of husbands' earnings less an adjustment to take account of wives' relative contributions to family earnings. A major element of this adjustment reflects the fraction of people who do not work for pay, that is, the fraction of people with zero earnings. Holding constant the dispersion in husbands' earnings and husbands' employment, increases in the fraction of wives at work for pay (reductions in the fraction of wives with no earnings) will reduce earnings inequality

\footnotetext{
${ }^{10}$ The correlation coefficients between $G$ and $\ln V$ and between $G_{H}$ and $\ln V_{H}$ are both 0.93 . Figures
} 4 and 5 show how similar are the variations in $G$ to those in $\ln V$. 
among husband-wife families. ${ }^{11}$ The effect of the increasing employment of wives in reducing family earnings inequality falls (if $\beta_{3}$ is positive as equation (6) suggests) as wives' employmentpopulation ratio grows - this is the logic for the quadratic term in $\left(m_{W} E_{W}\right) /\left(m_{H} E_{H}\right)$. In addition, as wives' earnings rise relatively to husbands' earnings (i.e., as $m_{W}$ rises relatively to $m_{H}$ ) so the importance of husbands' earnings inequality, $G_{H}$, in accounting for variations in family earnings inequality, $G$, falls.

How well does equation (1) describe the data on family earnings inequality? Column (1) of Table 3 presents the weighted least-squares of equation (1). In all, $G_{H},\left(m_{W} E_{W}\right) /\left(m_{H} E_{H}\right)$, and $\left[\left(m_{W} E_{W}\right) /\left(m_{H} E_{H}\right)\right]^{2}$ remove 98 percent of the variance in $G$. In fact, as shown by the estimates in column 2 of Table 3, in describing the variations across these experience and cohort cells, $G_{H}$ and $\left(m_{W} E_{W}\right) /\left(m_{H} E_{H}\right)$ alone remove over 97 percent of the variance in $G$. The estimates in columns (1) and (2) of Table 3 imply that increases in the wives' employment-population ratio or increases in the earnings of wives reduce family earnings inequality at observed values of the wives' employment and earnings. ${ }^{12}$

A component of the high correlations reported in columns (1) and (2) of Table 3

\footnotetext{
${ }^{11}$ Strictly, whether increases in the fraction of wives at work for pay will reduce family earnings inequality depends on the values of the $\beta_{2}$ and $\beta_{3}$ coefficients. We shall see shortly, however, that the estimated values of these coefficients justify the statement in the text for almost all the observed values of $\left(m_{W} E_{W}\right) /\left(m_{H} E_{H}\right)$ in the cohort-experience cells.

${ }^{12} \partial G / \partial E_{W}$ and $\partial G / \partial m_{W}$ are negative for almost all the values of the right-hand side variables. It is only at some high values of $\left(m_{W} E_{W}\right)$ for which this is not the case. This is the consequence of the excessive curvature placed on the relationship by the quadratic term. Indeed, when the quadratic expressions in equation (1) are replaced with a more flexible functional form (one in which a series of dummy variables indicate various categories of $\left.\left(m_{W} E_{W}\right) /\left(m_{H} E_{H}\right)\right), \partial G / \partial E_{W}$ and $\partial G / \partial m_{W}$ are always negative. When the Gini coefficients are replaced by other indicators of inequality (one is the variance of the logarithm of income and the other is the logarithm of the coefficient of variation of income), again a very large fraction (well over 90 percent) of the variation in family earnings dispersion is removed by a least-squares linear combination of right-hand side variables.
} 
between family earnings inequality and the right-hand side variables arises because any measurement error in husbands' earnings will automatically be contained in family earnings. To determine the degree to which such measurement error inflates the $R^{2}$ values, consider fitting equation (1) to cells in which the left-hand side and right-hand side variables are constructed from different underlying observations. Thus, in each cell, randomly allocate families into two groups: in one group, $G$, family earnings inequality, is formed and, in the second group, $G_{H}$ and ( $m_{W} E_{W}$ )$/\left(m_{H} E_{H}\right)$ are formed. Now estimate equation (1) where the left-hand side and right-hand side variables are constructed from different families in each cell. The results are contained in columns (3) and (4) of Table 3. The estimated coefficients in columns (3) and (4) are similar to those in columns (1) and (2) and the computed $R^{2}$ statistics for the equations in columns (3) and (4) are only a little below those in columns (1) and (2). The suggestion is that correlated measurement error is not a primary factor in accounting for the empirical performance of equation (1). ${ }^{13}$

\section{The Relative Importance of Husbands' Earnings and Wives’ Employment}

The estimates of equation (1) allow simulations of family earnings inequality to compute the relative importance for changes in family earnings inequality of increases in husbands' earnings inequality and of the increases in wives' relative earnings and employment. Simulations of equation (1) are hindered by the fact that, as Table 1 makes clear, observations on all years of

${ }^{13}$ Note that the right-hand side variables of equation (1) involve not only the employmentpopulation ratios of wives to husbands but also their relative earnings. One may inquire into the role of relative earnings by fitting

$$
G=\gamma_{0}+\gamma_{1} G_{H}+\gamma_{2}\left(E_{W} / E_{H}\right)+\gamma_{3}\left(E_{W} / E_{H}\right)^{2}+\varepsilon
$$

which omits relative earnings from the second two right-hand side variables. The weighted least squares estimates (with estimated standard errors in parentheses) of the $\gamma$ parameters are as follows: $\gamma_{1}=0.799(0.006), \gamma_{2}=0.108(0.046)$, and $\gamma_{3}=-0.126(0.033)$ with an $R^{2}$ of 0.985 . While the explanatory power of the right-hand side variables of equation $\left(1^{\prime}\right)$ is as great as those in column (1) of Table 3, the signs of the coefficient estimates of $\gamma_{2}$ and $\gamma_{3}$ are opposite those estimated for $\beta_{2}$ and $\beta_{3}$ above. Hence the presence of relative earnings makes a meaningful difference to the estimates. 
experience are lacking for every cohort. This means a flexible and accurate description of the variables on the right-hand side of equation (1) outside their observed values is first required. That is, let $R_{M}=m_{W} / m_{H}$ and $R_{E}=E_{W} / E_{H}$ and express $R_{M}$ and $R_{E}$, in addition to $G_{H}$, as general functions of experience and cohort as follows: $R_{M}=f(x, c), R_{E}=g(x, c)$, and $G_{H}=h(x, c)$. Numerical expressions for $f(x, c), g(x, c)$, and $h(x, c)$ allow equation (1) to be written

$$
\hat{G}=\hat{\beta}_{0}^{\prime}+\hat{\beta}_{1}^{\prime} \hat{h}(x, c)+\hat{\beta}_{2}^{\prime}[\hat{f}(x, c) \cdot \hat{g}(x, c)]+\hat{\beta}_{3}^{\prime}[\hat{f}(x, c) \cdot \hat{g}(x, c)]^{2}
$$

where the circumflexes represent estimated values. Now family earnings inequality may be simulated for different values of years of experience and cohort. For instance, denote the cohort entering the labor market in 1941-45, cohort 4, by $c_{4}$ and denote the cohort entering the labor market in 1971-75, cohort 10, by $c_{10}$. Once the forms of $f(x, c), g(x, c)$, and $h(x, c)$ are determined, we may ask what family earnings inequality would have looked like at each year of experience for cohort 10 if, say, relative earnings $R_{M}$ and $R_{E}$ had taken on their actual values for cohort 10 but husbands' earnings inequality, $G_{H}$, had remained at its cohort 4 values:

$$
\begin{aligned}
\hat{G}\left[x ; G_{H}(4), R_{M}(10), R_{E}(10)\right]= & \hat{\beta}_{0}^{\prime}+\hat{\beta}_{1}^{\prime} \hat{h}\left(x, c_{4}\right)+\hat{\beta}_{2}^{\prime}\left[\hat{f}\left(x, c_{10}\right) \cdot \hat{g}\left(x, c_{10}\right)\right]+ \\
& \hat{\beta}_{3}^{\prime}\left[\hat{f}\left(x, c_{10}\right) \cdot \hat{g}\left(x, c_{10}\right)\right]^{2}
\end{aligned}
$$

In this expression, relative earnings and employment assume the values associated with cohort 10 while the inequality of husbands' earnings assumes the values associated with cohort 4 . Therefore, the simulated values of family earnings inequality describe the impact of the change in the relative earnings and relative employment of wives holding constant husbands' earnings inequality. The impact on family earnings inequality of changes in husbands' earnings inequality holding constant 
wives’ relative earnings and employment can be assessed using

$$
\begin{gathered}
\hat{G}\left[x ; G_{H}(10), R_{M}(4), R_{E}(4)\right]=\hat{\beta}_{0}^{\prime}+\hat{\beta}_{1}^{\prime} \hat{h}\left(x, c_{10}\right)+\hat{\beta}_{2}^{\prime}\left[\hat{f}\left(x, c_{4}\right) \cdot \hat{g}\left(x, c_{4}\right)\right]+ \\
\hat{\beta}_{3}^{\prime}\left[\hat{f}\left(x, c_{4}\right) \cdot \hat{g}\left(x, c_{4}\right)\right]^{2}
\end{gathered}
$$

so that $R_{M}=m_{W} / m_{H}$ and $R_{E}=E_{W} / E_{H}$ assume the values of an earlier cohort, cohort 4, while $G_{H}$ assumes values associated with a recent cohort, cohort 10.

To implement these counterfactuals, we require an accurate description of the experience and cohort patterns in wives’ relative employment and earnings and husbands' earnings inequality; that is we need to fit $R_{M}=f(x, c), R_{E}=g(x, c)$, and $G_{H}=h(x, c)$. After investigating the implications of alternative specifications, we specified the variations in $R_{M}, R_{E}$, and $G_{H}$ by means of a fully interacted quintic function of years of experience and a linear function of cohort. The weighted least-squares estimates are presented in Table 4. Ninety-two percent of the variations in wives' relative earnings and relative employment and almost ninety-nine percent of the variations in husbands' earnings inequality are removed by these combinations of years of experience and cohort. Empirical estimates of $f(x, c), g(x, c)$, and $h(x, c)$ have now been determined.

Consider Figure 8 where the wide lines describe actual observations on $G$ for cohorts 4 and 10. The actual observations for cohort 4 are from 23 to 40 years of experience and those for cohort 10 are from 2 to 28 years of experience. The continuous dotted line plots the values implied for $G$ for the 1941-45 cohort from the estimates of $R_{M}=f(x, c), R_{E}=g(x, c)$, and $G_{H}=h(x, c)$ in Table 4 and the continuous solid line plots the values implied for $G$ for the 1971-75 cohort from the estimates of $R_{M}=f(x, c), R_{E}=g(x, c)$, and $G_{H}=h(x, c)$ in Table 4. Clearly, within the sample years, the implied series for $G$ does little more than smooth the raw data. The values for $G$ for the 1941-45 cohort are always below those for the 1971-75 cohort: in the years that overlap, the Gini coefficient 
is an average of 0.05 higher for the later cohort. To what extent is that increase attributable to greater earnings inequality among husbands and to what extent is it affected by the growth in wives' employment and earnings?

The implied values of $G$ for cohorts 1941-45 and 1971-75 in Figure 8 are reproduced in Figure 9. These are the dotted and continuous lines, respectively, in Figure 9. Figure 9 also presents some simulations of $G$ corresponding to different assumptions about husbands' earnings inequality, $G_{H}$, and about the relative employment and earnings of wives. Thus the series denoted $G H(4), R E(10), R m(10)$ plots the Gini coefficients when wives' relative employment and relative earnings assume their implied values for the tenth cohort whereas husbands' earnings inequality assumes its implied values for the fourth cohort. This series is the lowest of the four lines graphed in Figure 9. This means that family earnings inequality is least when husbands' earnings inequality takes on its values for the early cohort and when wives' employment and earnings take on their values for the later cohort. Expressed differently, relatively low husbands' earnings inequality and relatively high wives' employment and earnings contribute to lower family earnings inequality. The differences are most evident at younger years of experience.

The greatest values of inequality in family earnings in Figure 9 correspond to the line $G H(10), R E(4), R m(4)$ where wives' relative employment and relative earnings assume their implied values for the fourth cohort whereas husbands' earnings inequality assumes its implied values for the tenth cohort. In other words, higher values of husbands' earnings inequality and lower values of wives' employment and earnings result in greater family earnings inequality. The fact that the simulated series $G H(10), R E(4), R m(4)$ is closer to the implied series for cohort 10 ("1971-75 implied") and the fact that the simulated series $G H(4), R E(10), R m(10)$ is closer to the implied series for cohort 4 (“1941-45 implied”) indicates that variations in family earnings inequality are more 
closely tied to the movements in husbands' earnings inequality than to variations in wives' relative employment and earnings.

A summary of the contributions of the changes in $G_{H}$ and $\left(m_{W} E_{W}\right) /\left(m_{H} E_{H}\right)$ to the change in $G$ from the 1941-45 to the 1971-75 cohorts by experience is given in Table 5. Over this period, $G$ increased by 0.079 for the youngest couples (as shown in the first line of Table 5). $G_{H}$ increased by more than this, namely, by 0.100 . The relative increase in wives' employment and earnings partially offset the increase in $G_{H}$ and contributed -0.021 to the change in $G$. At each experience level, the increase in wives' employment and earnings offset the increases in husbands' earnings inequality and induced family earnings inequality to rise by less than it would otherwise have done. The relative contribution of wives' employment and earnings is especially marked at between 6 and 20 years of experience. Although the greater employment and earnings of wives has attenuated the growth in family earnings inequality, these movements are more than offset by increases in husbands' earnings inequality. ${ }^{14}$

\section{Earnings Inequality for Husbands and Wives Separately}

We turn now from describing family earnings inequality to the inequality of husbands' earnings and wives’ earnings separately with particular attention to the way in which market work patterns affect inferences about changes in inequality. Equation (2) above relates a measure of the dispersion in family earnings, namely, $V^{2}$, the square of the coefficient of variation of family earnings, to the same dispersion indicator for husbands' earnings and wives’ earnings, respectively, $\left(V_{H}\right)^{2}$ and $\left(V_{W}\right)^{2}$. This section will establish a useful relationship for $\left(V_{H}\right)^{2}$ and

\footnotetext{
${ }^{14}$ The greater sensitivity of changes in husbands' earnings inequality for family earnings inequality may be inferred directly from the estimates of equation (1) in Table 3. Using the estimates in column (1) and evaluating the estimates at sample mean values, the elasticity of $G$ with respect to $G_{H}$ is 0.880 whereas the elasticity of $G$ with respect to $\left(m_{W} E_{W}\right) /\left(m_{H} E_{H}\right)$ is -0.045 .
} 
$\left(V_{W}\right)^{2}$ separately that will allow us to assess the impact on earnings inequality of changes in the fraction of individuals (husbands and wives, in turn) in market employment.

Consider the variance in earnings for, say, husbands when some husbands work for pay and some do not. If $\sigma_{H}$ is the standard deviation of husbands' earnings (including both those with positive earnings and those with zero earnings), then

$$
{\sigma_{H}}^{2}=E_{H} \cdot s_{H}^{2}+E_{H} \cdot\left(1-E_{H}\right) \cdot m_{H}^{2}
$$

where $E_{H}$ is the employment-population ratio of husbands, $s_{H}{ }^{2}$ is the variance of earnings among husbands employed for pay, and $m_{H}{ }^{2}$ is the square of mean earnings of those husbands employed. ${ }^{15}$ Most research on earnings inequality focuses on $s_{H}$ or another metric of inequality among those with positive earnings only. However, equation (8) can be rearranged to derive a relationship between earnings inequality among workers only and earnings inequality among all people.

Converting to a scale-invariant measure of dispersion, let $V_{H}\left(=\sigma_{H} / \mu_{H}\right)$ denote the coefficient of variation of earnings among all husbands and $V_{H}^{e}\left(=s_{H} / m_{H}\right)$ the coefficient of variation of earnings among those husbands with positive earnings. Then equation (8) may be rewritten with the coefficient of variation as the indicator of inequality:

$$
\left(V_{H}\right)^{2}=E_{H} \cdot\left(V_{H}^{e}\right)^{2} \cdot\left(q_{H}\right)^{2}+E_{H} \cdot\left(1-E_{H}\right) \cdot\left(q_{H}\right)^{2}
$$

where $q_{H}=m_{H} / \mu_{H}$, the ratio of mean earnings among workers only to the mean earnings of all workers. Given $\mu_{H}=E_{H} \cdot m_{H}, q_{H}=\left(E_{H}\right)^{-1}$ and a convenient expression is arrived at that relates earnings inequality among all husbands to two variables, namely, earnings inequality among those husbands working for pay and the fraction of husbands at work for pay:

\footnotetext{
${ }^{15}$ Let $D=1$ if $y_{H}>0$ and $D=0$ if $y_{H}=0$. Then ${\sigma_{H}}^{2}=\mathscr{E}\left(y_{H}{ }^{2}\right)-\left[\mathscr{E}\left(y_{H}\right)\right]^{2}=\mathscr{E}\left[\left(D \cdot y_{H}\right)^{2}\right]$ $\left[\mathscr{E}\left(D \cdot y_{H}\right)\right]^{2}=p \cdot \mathscr{E}\left(y_{H}^{2} \mid D=1\right)-p^{2} \cdot\left[\mathscr{E}\left(y_{H} \mid D=1\right)\right]^{2}$ where $p=\operatorname{prob}(D=1)$. Adding and subtracting $p \cdot\left[\mathscr{E}\left(y_{H} \mid D=1\right)\right]^{2}$ and recognizing that $s_{H}{ }^{2}=\mathscr{E}\left(y_{H} \mid D=1\right)-\left[\mathscr{E}\left(y_{H} \mid D=1\right)\right]^{2}$ and that $m_{H}^{2}=\left[\mathscr{E}\left(y_{H} \mid D=1\right)\right]^{2}$, equation (8) in the text is derived.
} 


$$
\left(V_{H}\right)^{2}=\left(E_{H}\right)^{-1} \cdot\left(V_{H}^{e}\right)^{2}+\left(E_{H}\right)^{-1}-1
$$

Necessarily, $\left(V_{H}\right)^{2}$ exceeds $\left(V_{H}^{e}\right)^{2}$ : the dispersion of earnings including those with zero earnings exceeds the dispersion of earnings excluding non-workers. Equation (9) suggests that, neglecting selection, increases in employment reduce earnings inequality among all people with the size of the effect increasing with earnings inequality among workers. ${ }^{16}$

Of course, an equation analogous to (9) holds for wives:

$$
\left(V_{W}\right)^{2}=\left(E_{W}\right)^{-1} \cdot\left(V_{W}^{e}\right)^{2}+\left(E_{W}\right)^{-1}-1
$$

and, if equations (9) and (10) are substituted into equation (2), an expression is derived that relates family earnings inequality to earnings inequality among husbands and among wives, separately, and to their employment-population ratios:

$$
V^{2}=\left(B_{H}\right)^{2} \cdot\left[\left(E_{H}\right)^{-1} \cdot\left(V_{H}^{e}\right)^{2}+\left(E_{H}\right)^{-1}-1\right]+\left(B_{W}\right)^{2} \cdot\left[\left(E_{W}\right)^{-1} \cdot\left(V_{W}^{e}\right)^{2}+\left(E_{W}\right)^{-1}-1\right]+\psi
$$

where $\psi=2$. $r . B_{H^{*}} \cdot B_{W^{*}} \cdot V_{H} \cdot V_{W}$. In this way, the analysis in this section of earnings inequality for husbands and wives separately relates closely to the analysis of family earnings inequality in the previous section. Using the coefficient of variation as the measure of dispersion, equation (11) indicates that the impact of changes in, say, husbands' earnings inequality among workers on family earnings inequality depends on the fraction of husbands at work, $E_{H}$, and on the importance of husbands earnings in family earnings, $B_{H}$.

Equation (9) is an exact relationship that holds for the square of the coefficient of variation as a measure of inequality. In fact, other measures of earnings inequality among all people also exhibit the implied relationship with the employment-population ratio and earnings inequality among workers. ${ }^{17}$ Thus consider Figure 10 which plots the relationship for the 1961-65 cohort

\footnotetext{
${ }^{16}$ In other words, $\partial\left[\left(V_{H}\right)^{2}\right] / \partial\left(E_{H}\right)=-\left(E_{H}\right)^{-2}\left[\left(V_{H}^{e}\right)^{2}+1\right]<0$.

${ }^{17}$ The correlation coefficient between $\left(V_{H}\right)^{2}$ and $G_{H}$ is 0.91 and that between $\left(V_{W}\right)^{2}$ and $G_{W}$ is 0.89 .
} 
among $G_{H}$ (the Gini coefficient for husbands' earnings among all husbands both those working for pay and those not), $G_{H}{ }_{H}$ (the Gini coefficient for husbands' earnings only among those husbands working for pay), and $E_{H}$ (employment-population ratio of husbands). $G_{H}$ and $G_{H}{ }_{H}$ rise with experience although their values are closer at earlier years when $E_{H}$ is higher than it is in later years when $E_{H}$ is lower.

As for wives, let $G_{W}$ be the Gini coefficient for wives' earnings among all wives (those at market work and those not), $G^{e}{ }_{W}$ the Gini coefficient for wives' earnings only among those wives working for pay, and $E_{W}$ the employment-population ratio of wives. For the 1961-65 cohort , as shown in Figure 11, the employment-population ratio for these wives falls with experience, then rises, and then falls again. Earnings inequality among workers as measured by $G^{e}{ }_{W}$ tends to follow the opposite pattern rising with experience and then falling. Unlike husbands, for at least this cohort, earnings inequality among wives does not rise monotonically with experience. Earnings inequality among all wives - both those working for pay and those not working for pay - as measured by $G_{W}$ is greatest when wives’ employment-population ratio is least and earnings inequality is least when wives' employment-population ratio is highest. Of course, changes in the employment-population ratio will also affect the dispersion of earnings among workers only; that is, $\partial\left(G_{H}^{e}\right) / \partial E_{H}$ and $\partial\left(G^{e}{ }_{W}\right) / \partial E_{W}$ are unlikely to be zero. Whatever their signs, the suggestion in Figures 10 and 11 is that the relationship between the employment-population ratio and earnings inequality among all individuals is negative.

The preceding two graphs depict the relationships for a single cohort with respect to experience. Turning to the behavior of earnings inequality over time, the strong upward trends in the employment-population ratio of wives would suggest the possibility of quite different inferences 
about the movement of earnings inequality over time depending on whether the zero earnings of non-working wives are included in the computation of inequality. Figure 12 graphs these two measures of earnings inequality, $G_{W}$ and $G^{e}{ }_{W}$, as a function of cohort for wives with ten, twenty, and thirty years of experience. The $G_{W}$ series are shown as thin lines while the $G^{e}{ }_{W}$ series are depicted with thicker lines. For wives with twenty or thirty years of experience, the series on $G^{e}{ }_{W}$ suggests small changes in earnings inequality over time. The series on $G^{e}{ }_{W}$ for wives with ten years of experience (that is, younger women) falls with cohort before turning upwards. The corresponding series on $G_{W}$ all fall steeply over time indicating that the rising employment of women more than offsets trends in earnings inequality among workers. If we were to measure earnings inequality by taking account of the zero earnings of non-workers, we would conclude that earnings inequality among all wives fell over time.

Should we be concerned with earnings inequality among workers only or earnings inequality among all people, workers and non-workers? Some would respond that the answer depends on the reasons why people do not work. That is, perhaps some women seek and fail to obtain work at prevailing rates of pay because they are rationed out of jobs. Suppose these women are those recorded as unemployed. Then a compromise between choosing between $G_{W}$ and $G^{e}{ }_{W}$ as a measure of inequality is to count not all non-working wives in the computation of earnings inequality but simply those non-working wives who report being unemployed. Let $G^{U}{ }_{W}$ be the Gini coefficient of earnings inequality that includes all wives who are working for pay and all wives who are recorded as unemployed. The measurement of this series $G^{U}{ }_{W}$ across cohorts is shown in Figure 13 where it is compared with $G^{e}{ }_{W}$. Naturally each series on $G^{U}{ }_{W}$ lies above the corresponding series on $G^{e}{ }_{W}$ (that omits the unemployed). However, because the unemployed represent a small fraction of those wives not employed for pay, each $G^{U}{ }_{W}$ series is close to $G^{e}{ }_{W}$. (Note the scale of 
Figure 13's vertical axis.)

The contrast between the cross-cohort patterns in $G_{W}$ and $G^{e}{ }_{W}$ for wives - one measure of earnings inequality that includes those not working for pay and the other restricted to wives working for pay - raises the general question of whether additional differences in labor supply behavior affect inferences about changes in annual earnings inequality. To this effect, in addition to earnings inequality among (a) all wives (including those not working for pay) and (b) all working wives, construct measures of earnings inequality among those (c) working at least 700 annual hours, (d) working at least 1,400 hours per year, and (e) working at least 1,800 hours per year. For each of these groups, form the Gini coefficient of earnings inequality for wives and husbands separately. Across experience and cohort cells, the mean values and standard deviations of these Gini coefficients of annual earnings inequality among wives are reported in column (1) and those for husbands in column (3) of Table 6. Naturally, dispersion falls when inequality is measured over an increasingly selective group of wives. To determine whether the cross-cohort movements in earnings inequality vary across these different groups of wives - as suggested by the contrast between $G_{W}$ and $G^{e}{ }_{W}$ in Figure 12 - regress each Gini coefficient on experience fixed effects and a linear cohort trend. The weighted least-squares estimates of the coefficients on the cohort trend for wives are reported in column (2) and those for husbands in column (4) of Table $6 .{ }^{18}$

According to the estimates in column (2), while there are negative trends in annual earnings inequality for all wives (including non-workers), there are strong positive trends in

\footnotetext{
${ }^{18}$ Equations were also fitted with cohort fixed effects instead of a linear cohort trend. In most cases the linear cohort trend provides a good approximation to the cohort patterns. The exception is for wives working at least 1,400 hours and for wives working at least 1,800 hours. For these groups, the positive trend is much stronger for recent cohorts than is implied by a linear trend.
} 
inequality for full-time working wives (those working at least 1,800 hours per year). ${ }^{19}$ As increasingly selective work hours criteria are applied to the wives so the trends in earnings inequality tend to become more positive. The cohort trend variable implies that, for wives working at least 1,800 hours, the Gini coefficient increases by 0.03 over ten years whereas for all working wives the cohort trend implies an increase in the Gini coefficient of about one-fifth of this. Clearly quite dissimilar movements in inequality are implied for wives who work different market hours. ${ }^{20}$

The corresponding estimates on the cohort trend for husbands in column (4) of Table 6 (again allowing for experience fixed effects) are positive and, in most instances, do not vary across the different types of husbands as much as those of wives. Whereas inequality trends are negative for all wives (including non-workers), they are positive for all husbands (including non-workers). Of course, while wives exhibit strong positive trends in employment-population ratios, husbands have small declines and this accounts for the difference in these trends. ${ }^{21}$

${ }^{19}$ The Gini coefficients for women (not just wives) reported in Table 1 of Katz and Autor's (1999) survey describe the weekly earnings of those working 35 or more hours per week and working at least 40 weeks per year. So their measurements resemble the series here of those wives working at least 1,400 annual hours.

${ }^{20}$ The cohort trend variable increases by the value of unity for each successive cohort. Because each cohort is defined in five year intervals, a ten year change means an increase in the value of the cohort trend of two. According to the estimates in Table 6, the estimated coefficient on the cohort trend for wives working at least 1,800 hours is 0.0154 so over ten years the Gini coefficient increases by $.0308(0.0154 \times 2)$. By contrast, the estimated coefficient on the cohort trend for all working wives is 0.0035 so over ten years the Gini coefficient increases by .0070 ( $0.0035 \times 2)$. The estimated coefficient on the cohort trend for all working wives is a little over one-fifth (precisely, 0.227) of the estimated coefficient for full-time working wives.

${ }^{21}$ The estimates in columns (2) and (4) were also computed for two other indicators of earnings inequality: the ratio of the $90^{\text {th }}$ percentile to the $10^{\text {th }}$ percentile of earnings and the logarithm of the coefficient of variation of earnings. (However, when constructing earnings inequality among all people including zero earners, for many cells, the tenth earnings percentile corresponds to zero earnings so this is not a useful indicator of inequality for all people.) The general cohort trends for these two other indicators of inequality were similar to those reported for the Gini coefficient in Table 6 with the exception that a negative trend was estimated for the ratio of the $90^{\text {th }}$ to the $10^{\text {th }}$ 
One possible interpretation of these findings for wives - strong positive trends in earnings inequality for wives who work long hours and much smaller positive trends in earnings inequality for all working wives - is that wives' work hours have changed systematically at different points in the earnings distribution. Suppose the strong positive trends in inequality among those wives working full-time (at least 1,800 hours) approximates the increase in the dispersion of hourly earnings facing all workers. So hourly earnings have increased more at high wage levels than at low wage levels. This increase in hourly earnings inequality will be mapped into corresponding changes in annual earnings inequality if work hours do not change systematically at different points in the earnings distribution. However, suppose wives’ labor supply curves are not only positively-sloped with respect to hourly wages but also they are more wage-elastic at low wage levels than at high wages. This is compatible with income effects being greater at higher wage and hours levels. In this case, even though hourly earnings have increased more at high wage levels than at low wage levels, the positive work hours response is greater for wives with low wages and low earnings than for those with high wages and high earnings. In effect, greater increases in work hours for those with low hourly earnings than the increases in work hours for those at high hourly earnings has the effect of making the trends in annual earnings inequality smaller than the trends in hourly earnings inequality. ${ }^{22}$ So have wives’ work hours changed systematically at different points in the earnings

earnings percentile for all working wives and for wives working at least 700 hours.

${ }^{22}$ To be clear, write annual earnings, $y$, as the product of hourly earnings, $w$, and annual work hours, $h: y=w . h$ and, for convenience, use the ratio of earnings at the $90^{\text {th }}$ percentile to earnings at the $10^{\text {th }}$ percentile as the indicator of inequality for cohort $c$ at experience $x: y(9, c, x) / y(1, c, x)$. Form the change over cohorts in the logs of this measure of annual earnings inequality $\Delta \ln [y(9) / y$ (1)] $=\Delta \ln w(9)-\Delta \ln w(1)+\Delta \ln h(9)-\Delta \ln h$ (1). Suppose the labor supply functions for workers at the $90^{\text {th }}$ and $10^{\text {th }}$ percentiles may be written as $\ln h(9)=\eta \cdot \ln w(9)$ and $\ln h(1)=\mu$. $\ln$ $w(1)$ so

$\Delta \ln [y(9) / y(1)]=(1+\eta) \Delta \ln w(9)-(1+\mu) \Delta \ln w(1)$.

Even if $\Delta \ln w(9)-\Delta \ln w(1)>0$ (i.e., hourly earnings at the $90^{\text {th }}$ percentile of annual earnings 
distribution?

To answer this, examine changes in median hours worked at different points of the annual earnings distribution. That is, for wives in each cohort-experience cell, construct the median annual hours worked, $h^{M}$, at each $\pi$ percentile of the annual earnings $y_{W}$ distribution: $h^{M} \mid y_{W}=\pi$ from the fifth percentile to the ninety-fifth percentile. How has $h^{M} \mid y_{W}=\pi$ changed over time? To answer this, regress by weighted least-squares $h^{M} \mid y_{W}=\pi$ on experience fixed effects and on a linear cohort trend.

The estimated coefficients on the linear cohort trend for wives for each fifth percentile are graphed by the solid line in Figure $14 .^{23}$ All estimated trend coefficients are positive and the largest trend increases in median hours worked are for wives between the fifteenth and twenty-fifth earnings percentile. Above the twenty-fifth earnings percentile, the trend coefficients fall in value into the upper tail of the earnings distribution. The estimate of 93.82 for wives at the twenty-fifth earnings percentile implies that, over a ten year period, annual hours worked increased by 188 hours. By contrast, the estimate of 12.98 for wives at the seventy-fifth earnings percentile implies that, over a ten year period, annual hours worked for these women by merely 26 hours. So, among working wives, hours worked have increased more for those with low earnings than for those with high earnings. This differential trend has caused earnings inequality among all working wives

increase more than hourly earnings at the $10^{\text {th }}$ percentile), annual earnings inequality will increase less than hourly earnings inequality if the elasticity of labor supply of low wage workers, $\mu$, is sufficiently larger than the elasticity of labor supply of high wage workers, $\eta$ (assuming $\Delta \ln w$ ( 1 )$>0)$.

${ }^{23}$ Again, the cohort trend variable takes the value of unity for the 1926-30 cohort, two for the 193135 cohort, and so on up to the value of fourteen for the 1991-95 cohort, so an increase in the value of this trend by unity corresponds to a five year change. 
to increase less than among full-time working wives. ${ }^{24}$

This analysis is undertaken also for husbands. The trends in median work hours for husbands at different levels of annual earnings are given by the dashed line in Figure 14 . These trends tend to be smaller for husbands than for wives. The estimated trends for husbands at the $35^{\text {th }}$ earnings percentile or less are not significantly different from zero (applying conventional criteria) whereas most of the trends at higher earnings levels are greater than zero. Nevertheless these are small trends: the largest trend is estimated for husbands at the $85^{\text {th }}$ earnings percentile and the coefficient of 32.83 implies a ten year change of 66 annual hours which is less than three percent of the median (of 2,309).

Hence the labor supply dimension is a very important aspect of the changes in earnings inequality for wives but a much smaller component of the changes in earnings inequality for husbands. Quite different inferences about changes in earnings inequality - decreases in inequality among all wives (including non-workers), mild increases for all working wives, and substantial increases for full-time working wives - apply to wives according to their work behavior.

If inferences about changes in earnings inequality over time are affected by the labor supply behavior of individuals, are inferences about life cycle earnings inequality similarly sensitive? Figures 15 and 16 address this question by plotting the estimated fixed experience effects when Gini coefficients of annual earnings inequality are related to experience and cohort fixed effects. $^{25}$ Figure 15 pertains to wives and Figure 16 to husbands. For wives, the experience fixed

\footnotetext{
${ }^{24}$ By conventional statistical criteria, each of these estimated coefficients for wives is significantly greater than zero.

${ }^{25}$ In each figure, five weighted regression equations are fitted. One sample consists of all wives (husbands) including non-workers, another involves all working wives (husbands), another includes wives (husbands) working at least 700 annual hours, a fourth sample is of wives (husbands) working at least 1,400 annual hours, and the last sample are wives (husbands) working at least 1,800 hours.
} 
effects increase with years of experience for full-time workers but, as wives with fewer work hours are incorporated, so this pattern is attenuated. When annual earnings inequality among all wives including non-workers is analyzed, the experience effects reflect how employment probabilities change with experience. For husbands (Figure 16), earnings inequality increases with experience as it does for full-time working wives. However, the magnitude of the increases is greater for husbands than it is for wives. So inferences about life cycle patterns of annual earnings inequality are also affected by the labor supply behavior of the individuals whose earnings are being described.

\section{Conclusions}

This paper has analyzed earnings inequality in husband and wife families over the life cycle and over time by assembling pseudo-panel data from over thirty years of the Current Population Survey. The role of market work in understanding differences in earnings inequality has received special attention.

Family earnings inequality has increased over calendar time and increases with years since leaving school. A compact and accurate description relates the Gini coefficient of family earnings to variations in husbands' earnings inequality and to wives' relative employmentpopulation ratio and mean earnings. Changes in family earnings inequality over time have been driven principally by changes in husbands' earnings inequality. This supports the research effort into understanding the growth in wage inequality among men. Of secondary importance, family earnings inequality has been affected by the growth of wives’ earnings: if the employment of wives had not increased, the cohort growth in family earnings inequality would have been greater. The growing propensity of married women to work for pay has mitigated the increase in family earnings

In each case, the dependent variable is the Gini measure of annual earnings inequality. The reference experience level is two years of experience. 
inequality. The growth in the correlation between the earnings of husbands and that of wives has also contributed to the growth in family earnings inequality but its direct role is smaller than the other factors listed in this paragraph.

The second part of the paper examines the link between labor supply and earnings inequality among husbands and wives separately. Measures of earnings inequality covering people with different degrees of attachment to the labor market have been presented. Inferences about the extent and changes in earnings inequality are sensitive to alternative labor supply definitions especially in the case of wives. Trends in earnings inequality among wives are negative if the population consists of all wives, both workers and non-workers. Alternatively, among full-time workers, earnings inequality for wives has trended upwards. Market work hours for wives have increased most for those at the lower part of the earnings distribution. These links among wives between changes in earnings inequality and labor supply decisions warrant more research.

Finally, note that the research in this paper is directed towards understanding movements in the income inequality of families and in the income inequality of husbands and wives. A related but distinct issue concerns the inequality of consumption across and within families. Movements in consumption inequality do not mirror those in earnings inequality ${ }^{26}$ and we conjecture that a decomposition analogous to that used in this paper may help understand how movements in the inequality of family consumption relate to movements in the consumption inequality of husbands and wives.

\footnotetext{
${ }^{26}$ See, for instance, the information for Britain contained in Lise and Seitz (2004).
} 


\section{$\underline{\text { References }}$}

Burkhauser, Richard V., J. S. Butler, Shuaizhang Feng, and Andrew J. Houtenville, "Long Term Trends in Earnings Inequality: What the CPS Can Tell Us”, Economics Letters, 82 (2), 2004, 295299.

Cancian, Maria, Sheldon Danziger, and Peter Gottschalk, "Working Wives and Family Income Inequality among Married Couples”, in Sheldon Danziger and Peter Gottschalk, eds., Uneven Tides: Rising Inequality in America, Russell Sage Foundation, New York, 1993, 195-221.

Cancian, Maria, and Deborah Reed, “Assessing the Effects of Wives’ Earnings on Family Income Inequality”, Review of Economics and Statistics, 80 (1), February 1998, 73-79.

Congressional Budget Office, United States, Historical Effective Tax Rates: 1979 to 2003, December 2005, http://www.cbo.gov/ftpdoc.cfm?index=7000\&type=1.

Daly, Mary C., and Robert G. Valletta, “Inequality and Poverty in the United States: The Effects of Rising Dispersion on Men’s Earnings and Changing Family Behavior”, Economica, 73, February 2006, 75-98.

Gronau, Reuben, “Inequality of Family Income: Do Wives’ Earnings Matter”, Population and Development Review, 8 , Supplement, 1982, 119-36.

Hyslop, Dean R., "Rising U.S. Earnings Inequality and Family Labor Supply: The Covariance Structure of Intrafamily Earnings”, American Economic Review, 91 (4), September 2001, 755-77.

Katz, Lawrence F., and David H. Autor, "Changes in the Wage Structure and Earnings Inequality” in Orley Ashenfelter and David Card, eds., Handbook of Labor Economics Vol. 3A, Elsevier, Amsterdam, 1999, 1463-1555.

Lehrer, Evelyn, and Marc Nerlove, “The Impact of Female Work on Family Income Distribution: Black-White Differentials”, Review of Income and Wealth, Series 27 (4), December 1981, 423-31.

Lise, Jeremy, and Shannon Seitz, "Consumption Inequality and Intra-Household Allocations”, Queen’s University, Department of Economics, December 2004.

Pencavel, John, “Assortative Mating by Schooling and the Work Behavior of Wives and Husbands”, American Economic Review, (Papers and Proceedings) 88 (2), May 1998, 326-29.

Pencavel, John, “A Life Cycle Perspective on Changes in Earnings Inequality among Married Men and Women”, Review of Economics and Statistics, 2006, forthcoming.

Smith, James P., “The Distribution of family Earnings”, Journal of Political Economy, 87 (5), Part 2, October 1979, S163-S192. 
Table 1

Definitions of Cells by Cohort and Experience

(omitting cells with fewer than one thousand husband-wife pairs)

\begin{tabular}{ccccc} 
cohort & $\begin{array}{c}\text { years of } \\
\text { schooling } \\
\text { completion }\end{array}$ & $\begin{array}{c}\text { minimum years } \\
\text { of experience }\end{array}$ & $\begin{array}{c}\text { maximum years } \\
\text { of experience }\end{array}$ & $\begin{array}{c}\text { number of } \\
\text { cells }\end{array}$ \\
1 & $1926-30$ & 39 & 44 & 6 \\
2 & $1931-35$ & 33 & 44 & 12 \\
3 & $1936-40$ & 28 & 44 & 17 \\
4 & $1941-45$ & 23 & 44 & 22 \\
5 & $1946-50$ & 18 & 43 & 26 \\
6 & $1951-55$ & 13 & 42 & 30 \\
7 & $1956-60$ & 8 & 40 & 33 \\
8 & $1961-65$ & 3 & 37 & 35 \\
9 & $1966-70$ & 2 & 32 & 31 \\
10 & $1971-75$ & 2 & 28 & 27 \\
11 & $1976-80$ & 2 & 23 & 22 \\
12 & $1981-85$ & 2 & 18 & 17 \\
13 & $1986-90$ & 3 & 13 & 11 \\
14 & $1991-95$ & 3 & 7 & 5 \\
\hline all & $1926-1995$ & 2 & 44 & 294 \\
\hline
\end{tabular}

An individual's experience is defined as the minimum of (1) her years of age minus her years of schooling minus 6 and (2) her years of age minus seventeen. Then an individual's cohort is defined as the calendar year in which her experience is zero. 
Table 2

Descriptive Statistics on Variables for 294 Experience-Cohort Cells

$\begin{array}{lccccc}1 & V^{2} & 0.601 & 0.253 & 0.234 & 1.600 \\ 2 & \left(V_{H}\right)^{2} & 0.820 & 0.406 & 0.256 & 2.598 \\ 3 & \left(V_{W}\right)^{2} & 1.982 & 0.727 & 0.832 & 5.252 \\ 4 & V_{H} & 0.882 & 0.206 & 0.506 & 1.612 \\ 5 & V_{W} & 1.386 & 0.244 & 0.912 & 2.292 \\ 6 & \left(B_{H}\right)^{2} & 0.580 & 0.087 & 0.408 & 0.765 \\ 7 & \left(B_{W}\right)^{2} & 0.061 & 0.028 & 0.016 & 0.131 \\ 8 & B_{H} & 0.760 & 0.057 & 0.639 & 0.875 \\ 9 & B_{W} & 0.240 & 0.057 & 0.125 & 0.361 \\ 10 & r & 0.057 & 0.065 & -0.065 & 0.327 \\ & & & & & \\ 11 & \ln V & -0.293 & 0.190 & -0.727 & 0.235 \\ 12 & \ln V_{H} & -0.151 & 0.225 & -0.681 & 0.477 \\ 13 & \ln B_{H} & -0.278 & 0.076 & -0.449 & -0.134\end{array}$


Table 3

Describing Variations in the Gini Coefficient of Family Earnings

\begin{tabular}{|c|c|c|c|c|}
\hline & (1) & (2) & (3) & (4) \\
\hline constant & $\begin{array}{c}0.093 \\
(0.006)\end{array}$ & $\begin{array}{c}0.063 \\
(0.003)\end{array}$ & $\begin{array}{c}0.106 \\
(0.010)\end{array}$ & $\begin{array}{c}0.075 \\
(0.005)\end{array}$ \\
\hline$G_{H}$ & $\begin{array}{c}0.798 \\
(0.007)\end{array}$ & $\begin{array}{c}0.784 \\
(0.007)\end{array}$ & $\begin{array}{c}0.773 \\
(0.012)\end{array}$ & $\begin{array}{c}0.759 \\
(0.012)\end{array}$ \\
\hline$\left(m_{W} E_{W} / m_{H} E_{H}\right)$ & $\begin{array}{c}-0.292 \\
(0.039)\end{array}$ & $\begin{array}{l}-0.054 \\
(0.006)\end{array}$ & $\begin{array}{l}-0.303 \\
(0.066)\end{array}$ & $\begin{array}{l}-0.060 \\
(0.009)\end{array}$ \\
\hline$\left(m_{W} E_{W} / m_{H} E_{H}\right)^{2}$ & $\begin{array}{c}0.360 \\
(0.058)\end{array}$ & & $\begin{array}{c}0.369 \\
(0.099)\end{array}$ & \\
\hline$R^{2}$ & 0.979 & 0.975 & 0.939 & 0.934 \\
\hline see & 0.010 & 0.011 & 0.017 & 0.017 \\
\hline
\end{tabular}

For both the estimates in columns (1) and (2) and for those in columns (3) and (4), the mean of $G$ is 0.391 with a standard deviation of 0.067 . 
Table 4

Weighted Least-Squares Estimates of Earnings Inequality, Relative Employment, and Relative Earnings as Functions of Experience and Cohort

(estimated standard errors in parentheses)

\begin{tabular}{|l|c|c|c|}
\hline & \multicolumn{3}{|c|}{ left-hand side variable } \\
\hline & $G_{H}$ & $R_{E}=E_{W} / E_{H}$ & $R_{M}=m_{W} / m_{H}$ \\
\hline constant & 0.170 & 1.029 & 0.535 \\
\hline$x$ & -0.030 & -0.255 & -0.159 \\
\hline$x^{2}$ & $0.469(10)^{-2}$ & 0.024 & 0.015 \\
\hline$x^{3}$ & $-0.220(10)^{-3}$ & $-0.999(10)^{-3}$ & $-0.618(10)^{-3}$ \\
\hline$x^{4}$ & $0.442(10)^{-5}$ & $0.189(10)^{-4}$ & $0.119(10)^{-4}$ \\
\hline$x^{5}$ & $-0.320(10)^{-7}$ & $-0.137(10)^{-6}$ & $-0.895(10)^{-7}$ \\
\hline$C$ & 0.016 & $-0.557(10)^{-2}$ & $0.822(10)^{-3}$ \\
\hline C. ${ }^{-3}$ & $0.239(10)^{-2}$ & 0.017 & 0.015 \\
\hline C. $x^{2}$ & $-0.282(10)^{-3}$ & $-0.167(10)^{-2}$ & $-0.154(10)^{-2}$ \\
\hline C. $x^{3}$ & $0.116(10)^{-4}$ & $0.730(10)^{-4}$ & $0.683(10)^{-4}$ \\
\hline C. $x^{4}$ & $-0.209(10)^{-6}$ & $-0.148(10)^{-5}$ & $-0.144(10)^{-5}$ \\
\hline C. $x^{5}$ & $0.159(10)^{-8}$ & $0.114(10)^{-7}$ & $0.115(10)^{-7}$ \\
\hline & & & 0.924 \\
\hline$R^{2}$ & 0.985 & 0.922 & \\
\hline
\end{tabular}


Table 5

Changes in the Gini Coefficient from the 1941-45 to 1971-75 Cohorts by Experience

\begin{tabular}{|c|c|c|c|}
\hline experience & change in $G$ & change in $G_{H}$ & $\begin{array}{c}\text { change in } \\
\left(m_{W} E_{W}\right) /\left(m_{H} E_{H}\right)\end{array}$ \\
\hline$<6$ & 0.079 & 0.100 & -0.021 \\
\hline $6-10$ & 0.064 & 0.104 & -0.040 \\
\hline $11-15$ & 0.053 & 0.092 & -0.039 \\
\hline $16-20$ & 0.048 & 0.077 & -0.029 \\
\hline $21-25$ & 0.050 & 0.068 & -0.018 \\
\hline $26-30$ & 0.062 & 0.072 & -0.010 \\
\hline $31-35$ & 0.084 & 0.088 & -0.004 \\
\hline
\end{tabular}


Table 6

Mean Values, Standard Deviations, and Estimates of the Cohort Trend in Earnings Inequality for Wives and Husbands by the Extent of Their Market Work

\begin{tabular}{|l|l|c|c|c|c|}
\hline \multirow{2}{*}{\multicolumn{2}{|c|}{}} & \multicolumn{2}{|c|}{ wives } & \multicolumn{2}{c|}{ husbands } \\
\cline { 3 - 6 } \multicolumn{2}{|c|}{} & $(1)$ & $(2)$ & $(3)$ & $(4)$ \\
\cline { 3 - 6 } & $\begin{array}{c}\text { mean } \\
\text { (stand dev) }\end{array}$ & $\begin{array}{c}\text { trend } \\
\text { estimates }\end{array}$ & $\begin{array}{c}\text { mean } \\
\text { (stand dev) }\end{array}$ & $\begin{array}{c}\text { trend } \\
\text { estimates }\end{array}$ \\
\hline 1 & all (incl. non-workers) & $\begin{array}{c}0.653 \\
(0.076)\end{array}$ & $\begin{array}{c}-0.0277 \\
(0.0007)\end{array}$ & $\begin{array}{c}0.439 \\
(0.084)\end{array}$ & $\begin{array}{c}0.0185 \\
(0.0004)\end{array}$ \\
\hline 2 & all workers & $\begin{array}{c}0.377 \\
(0.027)\end{array}$ & $\begin{array}{c}0.0035 \\
(0.0005)\end{array}$ & $\begin{array}{c}0.319 \\
(0.042)\end{array}$ & $\begin{array}{c}0.0183 \\
(0.0005)\end{array}$ \\
\hline 3 & working $\geq 700$ hours & $\begin{array}{c}0.375 \\
(0.023)\end{array}$ & $\begin{array}{c}0.0036 \\
(0.0004)\end{array}$ & $\begin{array}{c}0.309 \\
(0.299)\end{array}$ & $\begin{array}{c}0.0178 \\
(0.0005)\end{array}$ \\
\hline 4 & working $\geq 1,400$ hours & $\begin{array}{c}0.292 \\
(0.032)\end{array}$ & $\begin{array}{c}0.0132 \\
(0.0005)\end{array}$ & $\begin{array}{c}0.299 \\
(0.041)\end{array}$ & $\begin{array}{c}0.0173 \\
(0.0005)\end{array}$ \\
\hline \multirow{2}{*}{5} & working $\geq 1,800$ hours & $\begin{array}{c}0.278 \\
(0.033)\end{array}$ & $\begin{array}{c}0.0154 \\
(0.0005)\end{array}$ & $\begin{array}{c}0.296 \\
(0.042)\end{array}$ & $\begin{array}{c}0.0173 \\
(0.0005)\end{array}$ \\
\hline
\end{tabular}

In columns (1) and (3), standard deviations are in parentheses beneath mean values. The entries in columns (2) and (4) under "trend estimates" are the estimated values of weighted least-squares coefficients attached to a linear cohort trend in regressions in which the Gini coefficient of earnings inequality is regressed on experience fixed effects and a linear cohort trend. In columns (2) and (4), estimated standard errors are in parentheses beneath estimated coefficients. For all but two cases, there are 294 experience-cohort cells. For wives working at least 1,400 annual hours and wives working at least 1,800 annual hours, cells with less than 300 underlying observations on these wives were omitted and this results in 279 experience-cohort cells for wives in line 4 and 263 experiencecohort cells in line 5. 
Figure 1

Gini Coefficients for Cohorts 6 and 9: Including and Excluding Nonlabor Income

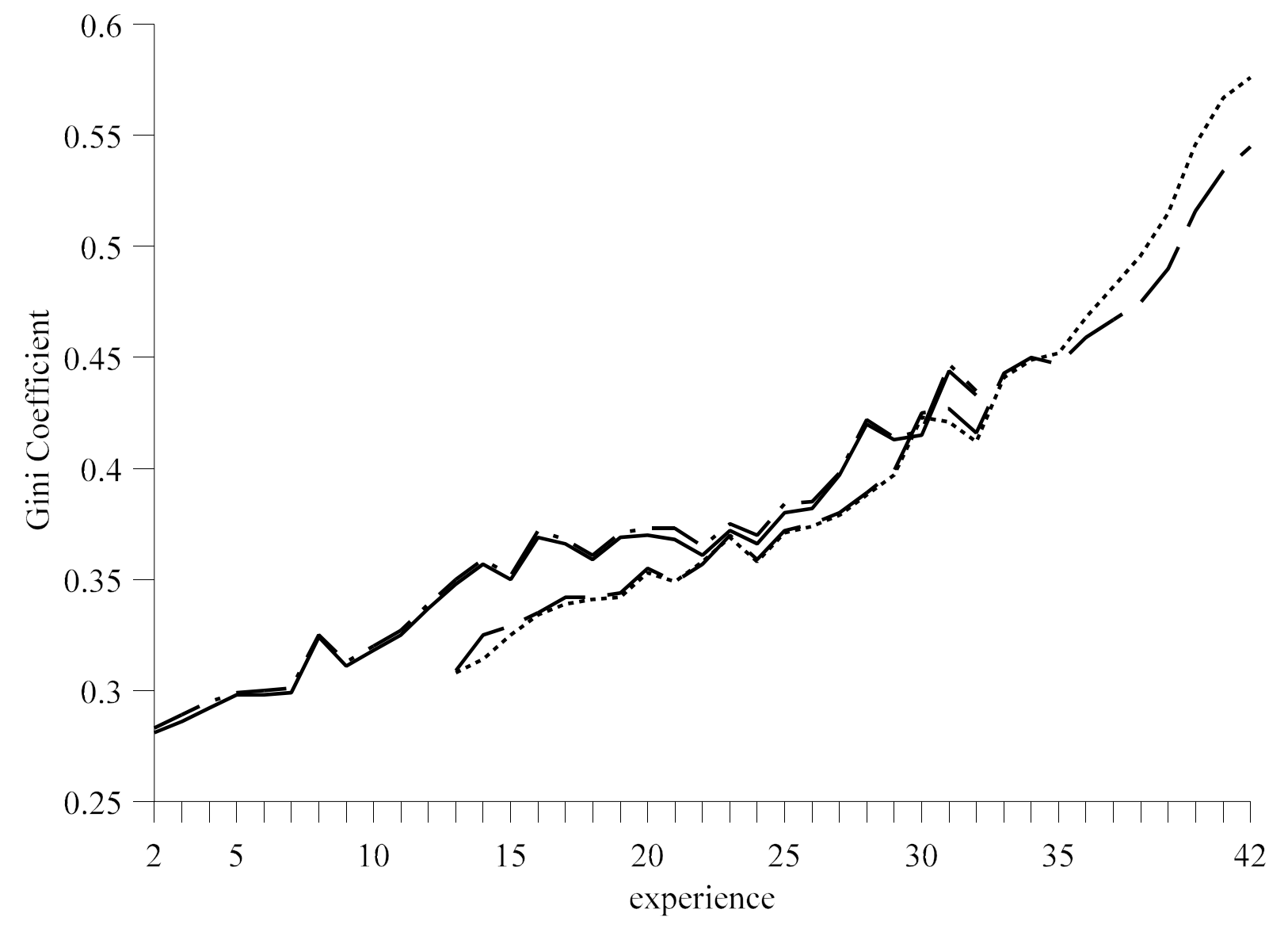

cohort 6 , excl N $-\operatorname{cohort} 6$, incl $\mathrm{N}$ $\longrightarrow \operatorname{cohort} 9, \operatorname{excl} \mathrm{N}-\cdots \operatorname{cohort} 9$, incl $\mathrm{N}$

“excl N” means excluding nonlabor income and “incl N” means including nonlabor income. 
Figure 2

Frequency Distribution of $r$

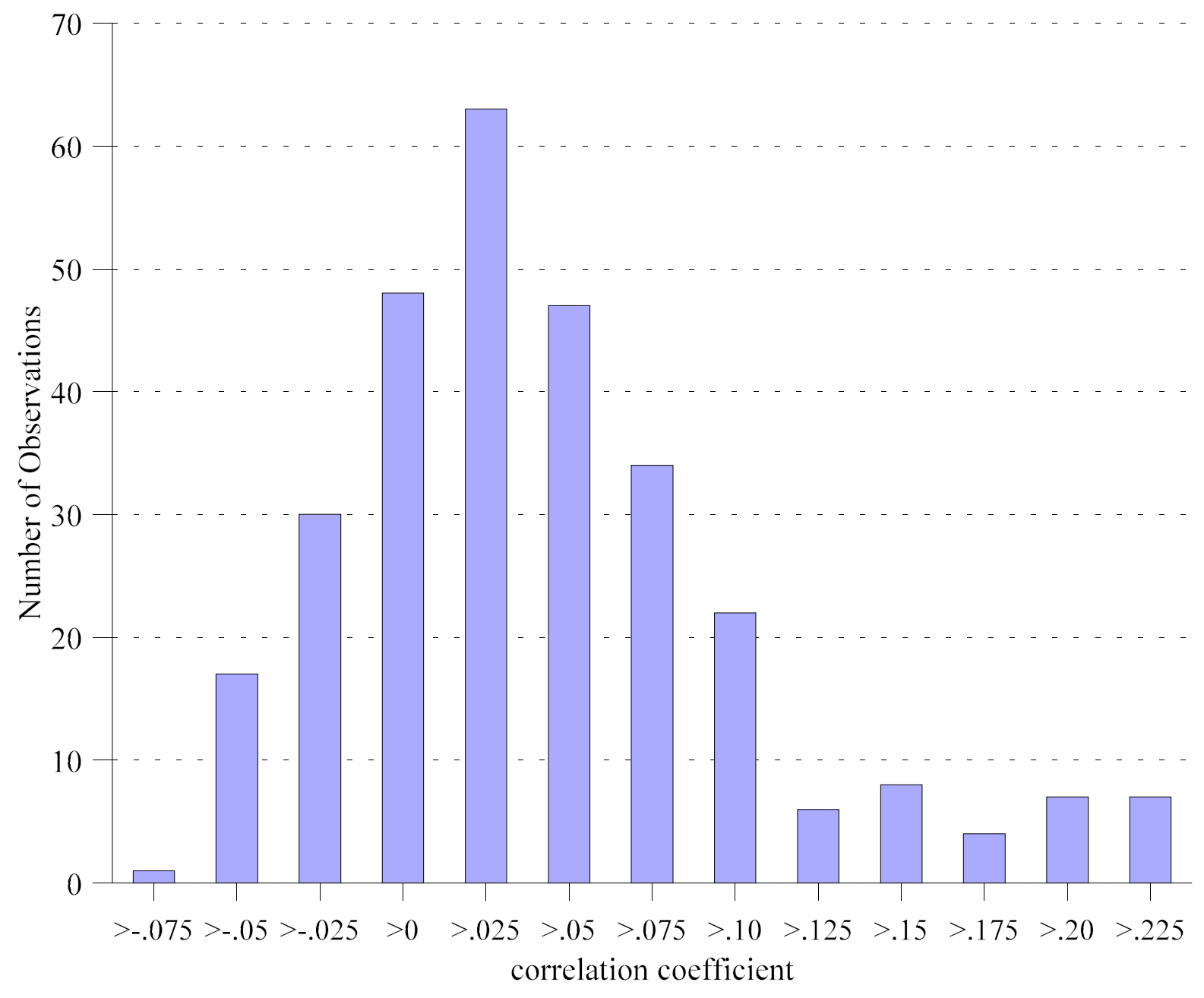


Figure 3

Absolute Value of $\left\{V^{2}-\left[\left(B_{H}\right)^{2} \cdot\left(V_{H}\right)^{2}+\left(B_{W}\right)^{2} \cdot\left(V_{W}\right)^{2}\right]\right\} / V^{2}$ by Cohort and Experience
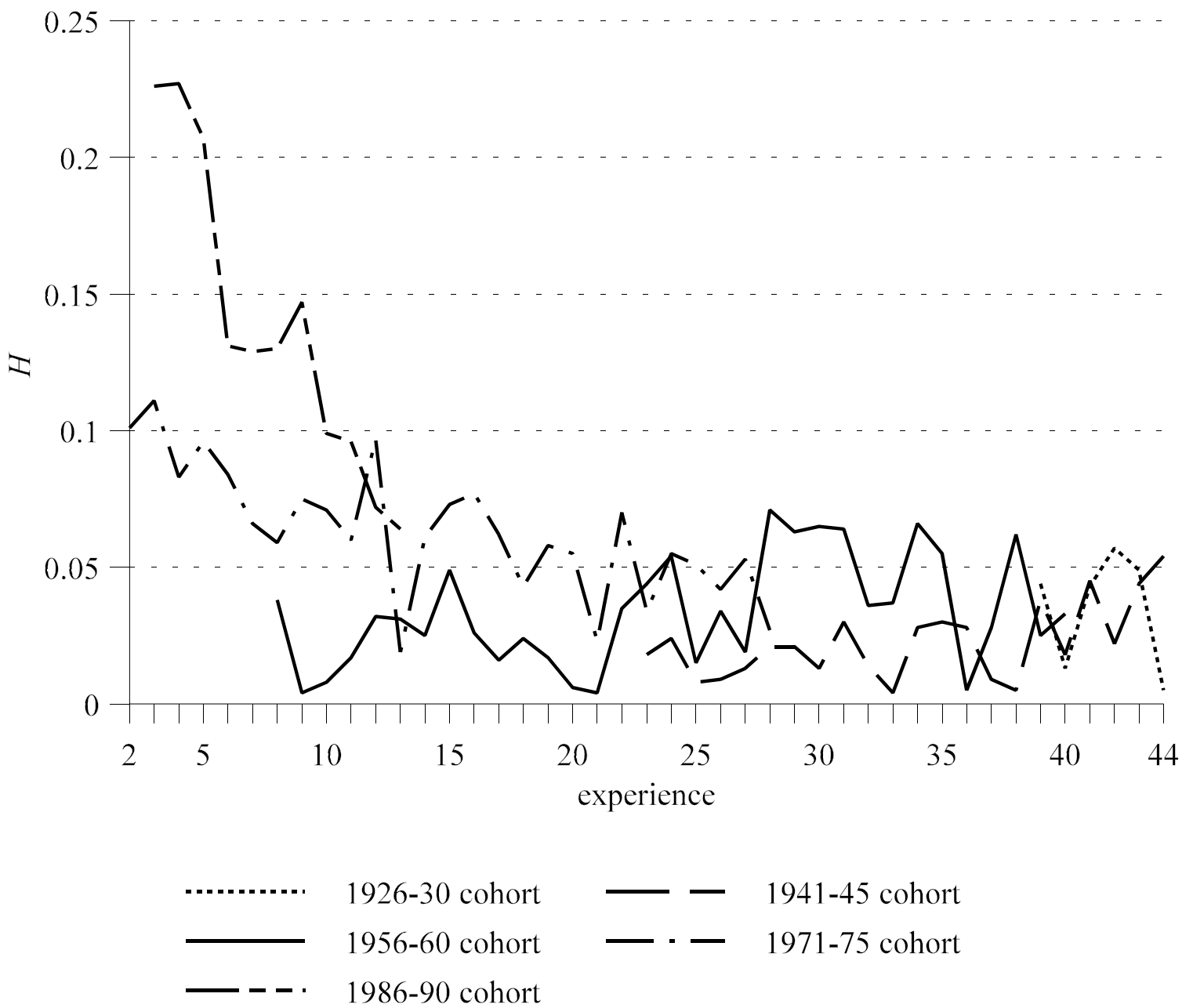
Figure 4

Values of $\ln V$ by Cohort and Experience
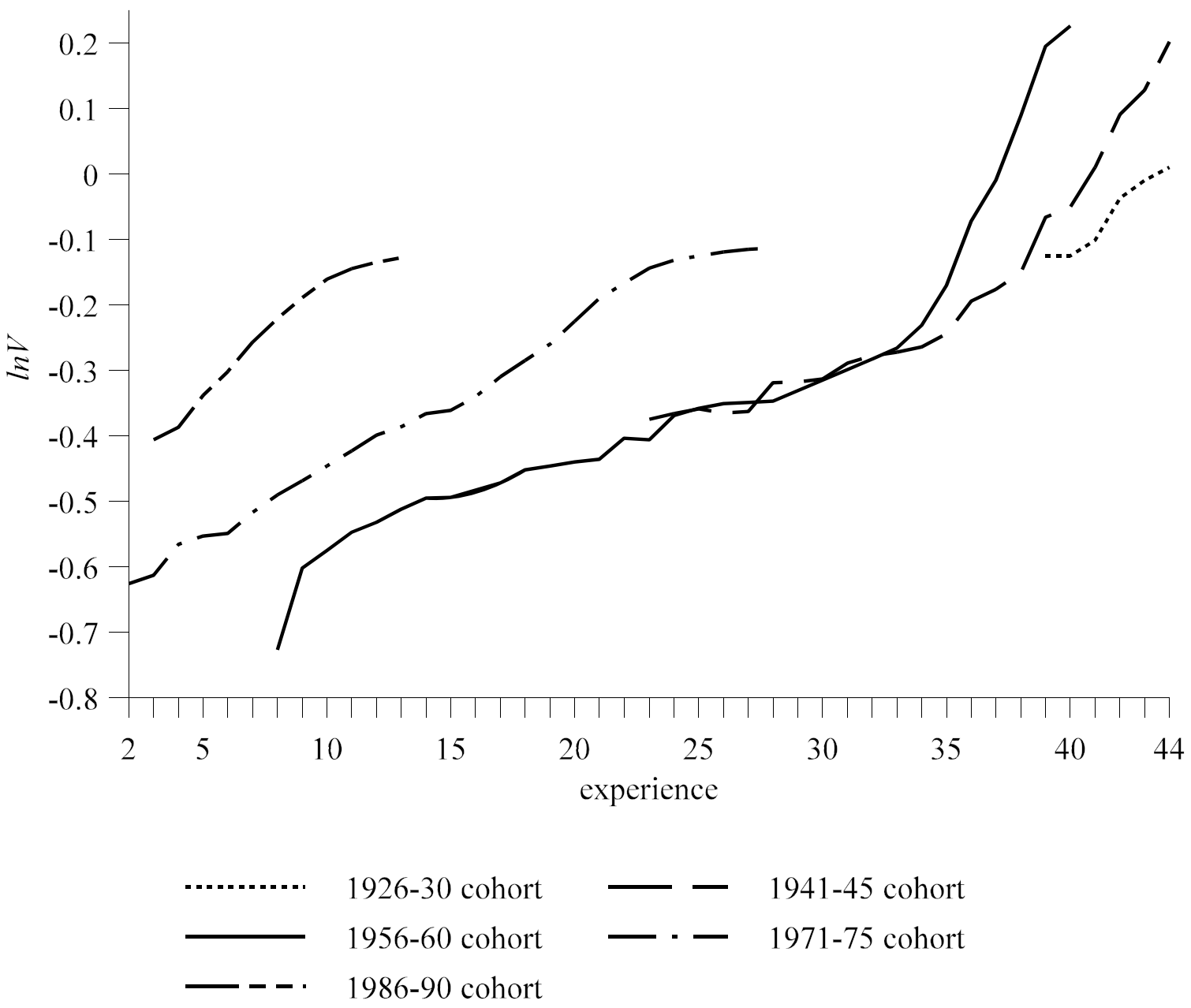
Figure 5

Values of Gini Coefficients by Cohort and Experience
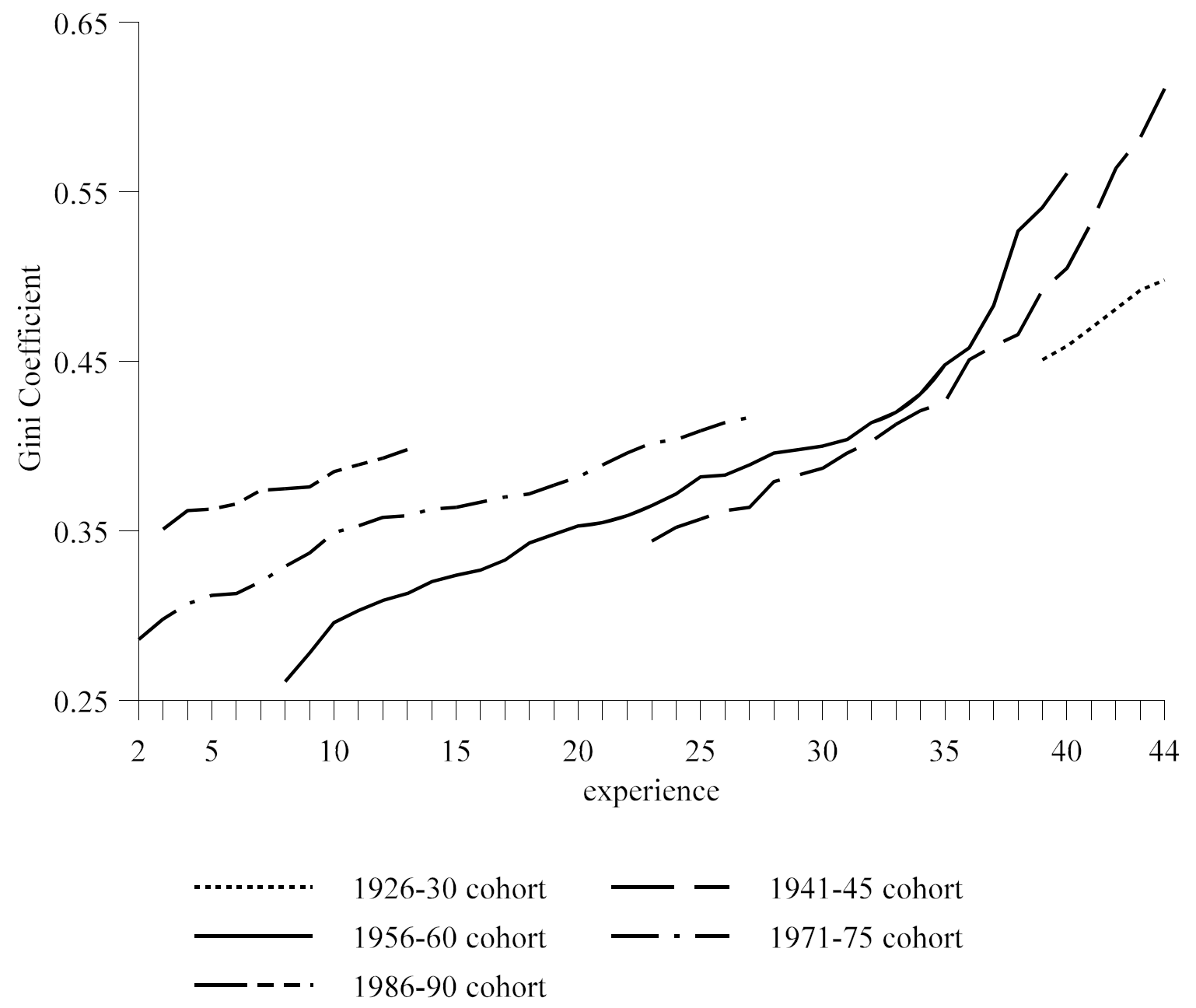
Figure 6

$-\ln \left[1+\left(m_{W} \cdot E_{W}\right) /\left(m_{H} E_{H}\right)\right]+\left(m_{W} \cdot E_{W}\right) /\left(m_{H} E_{H}\right)$

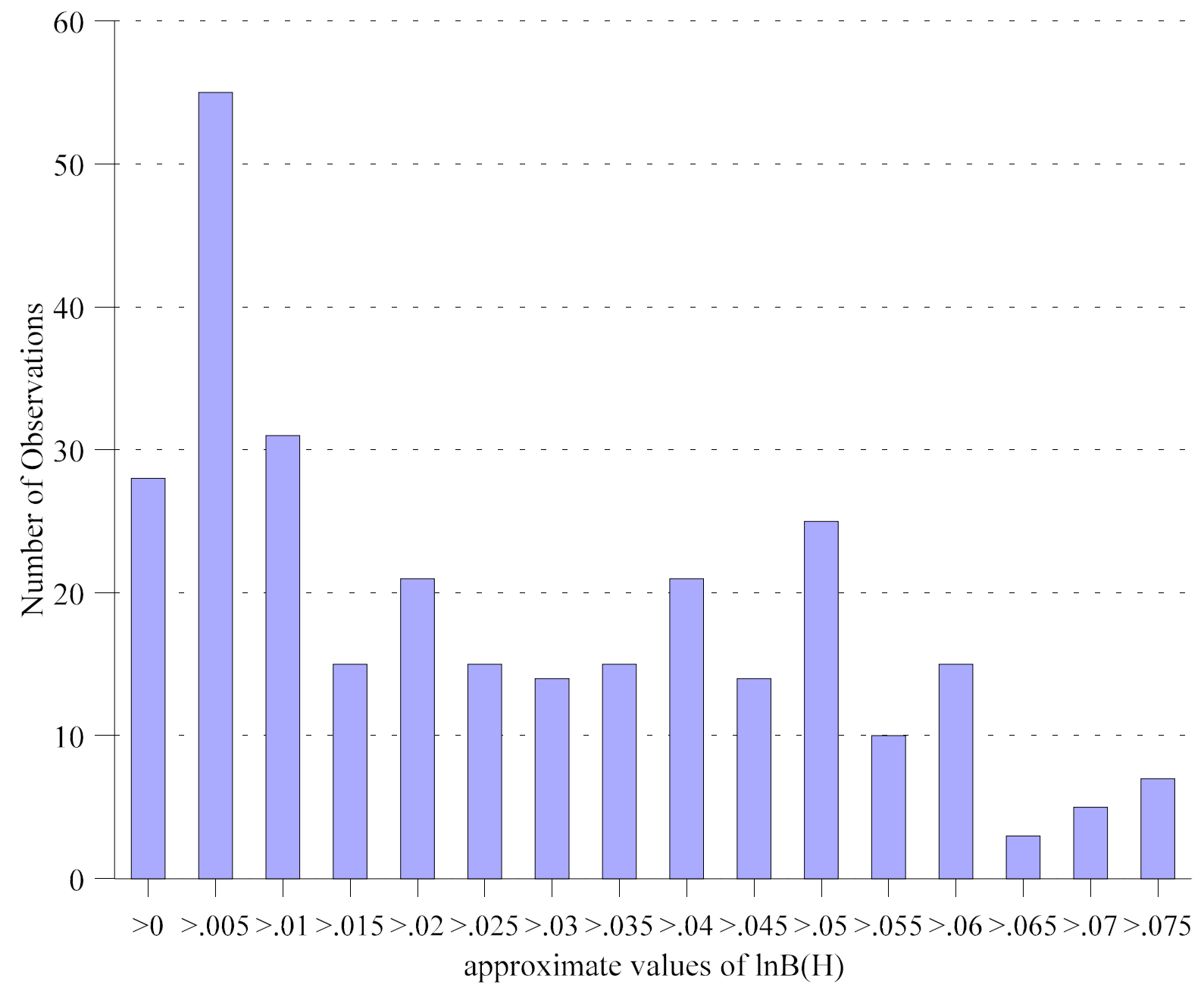


Figure 7

$$
\ln \left[1+\left(B_{w} / B_{H}\right)^{2}\left(V_{W} / V_{H}\right)^{2}\right]-\left(B_{w} / B_{H}\right)^{2}\left(V_{W} / V_{H}\right)^{2}
$$

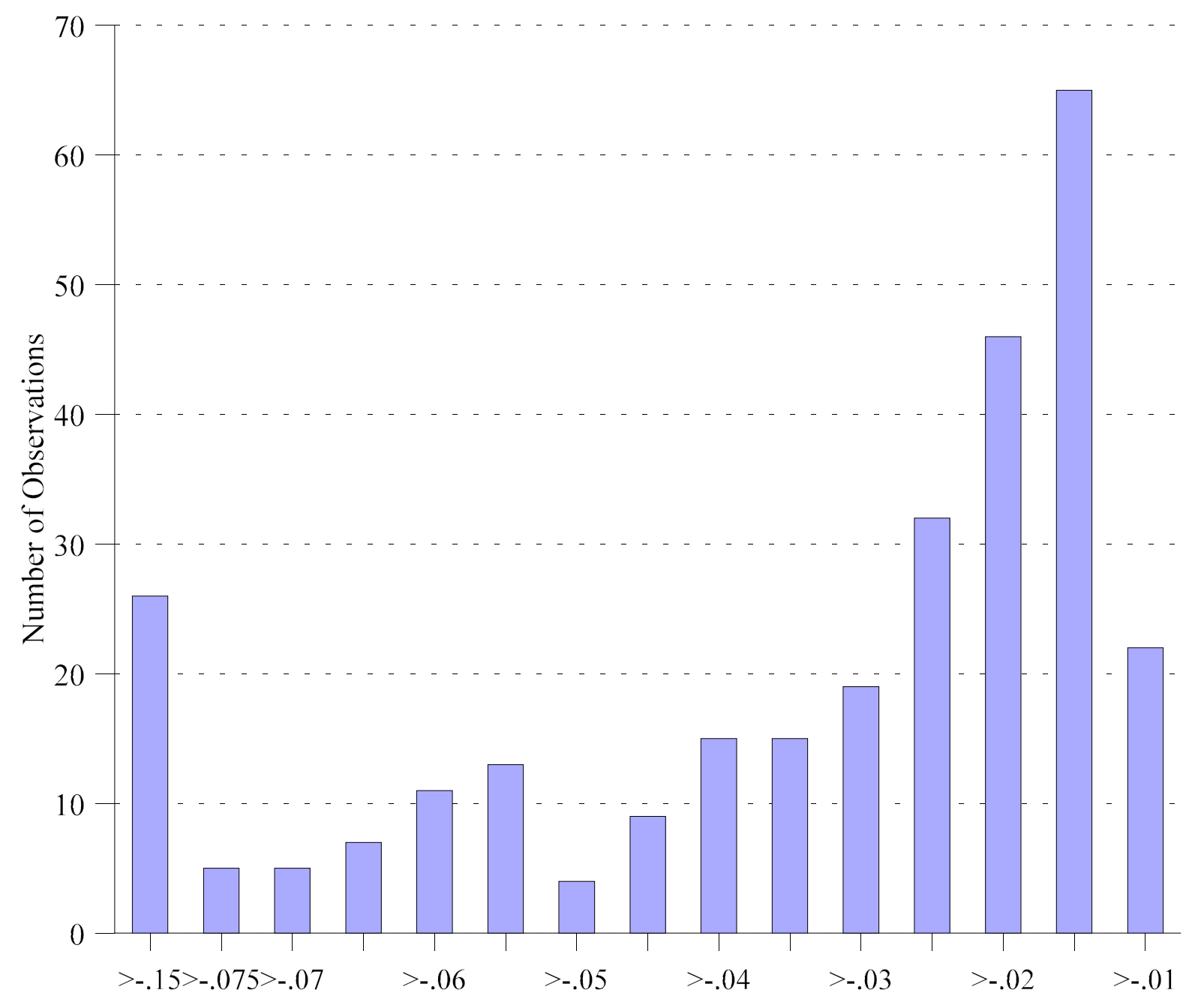

Except for the first and last categories, each bar corresponds to an interval 0.005 wide. Thus, ">-.075" means "the interval from -.075 to -.070" and ">-.07" means "the interval from -.070 to -.065 ". The first category ">-.15" spans the interval from -.15 to -0.75 . The last category ">-.01" spans the interval from -.01 to -.005 . 
Figure 8

Gini Coefficients by Experience: Actual and Implied for the 1941-45 and 1971-75 Cohorts
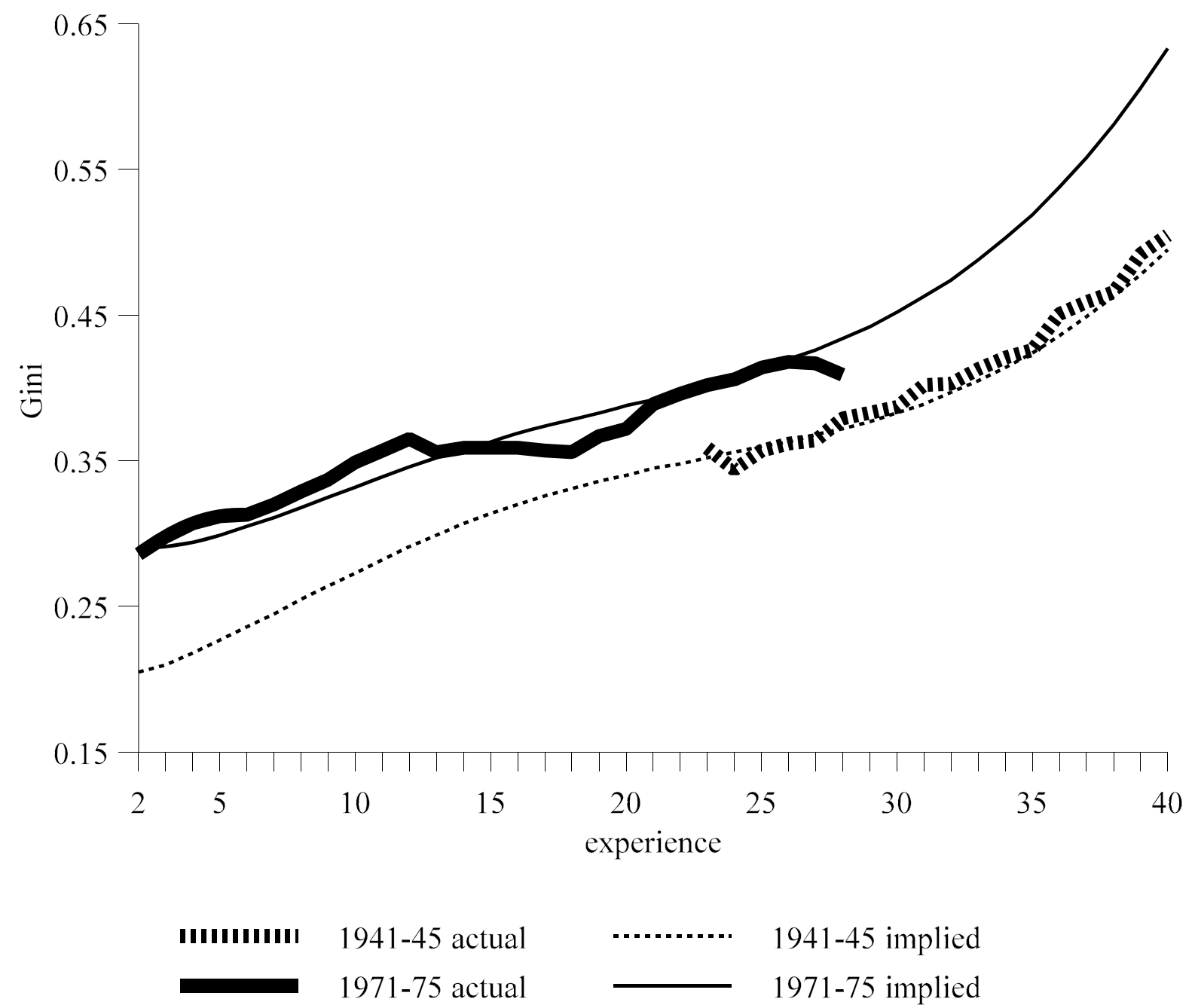

The wide lines plot the actual observations on the Gini coefficients for the 1941-45 and 1971-75 cohorts. The continuous dotted line plots the values implied for the Gini coefficients for the 1941-45 cohort from the estimates of $R_{M}=f(x, c), R_{E}=g(x, c)$, and $G_{H}=h(x, c)$ in Table 4 and the continuous solid line plots the values implied for the Gini coefficients for the 1971-75 cohort from the estimates of $R_{M}=f(x, c), R_{E}=g(x, c)$, and $G_{H}=h(x, c)$ in Table 4 . 


\section{Figure 9}

Gini Coefficients by Experience: Implied and Extrapolated for the 1941-45 and 1971-75 Cohorts

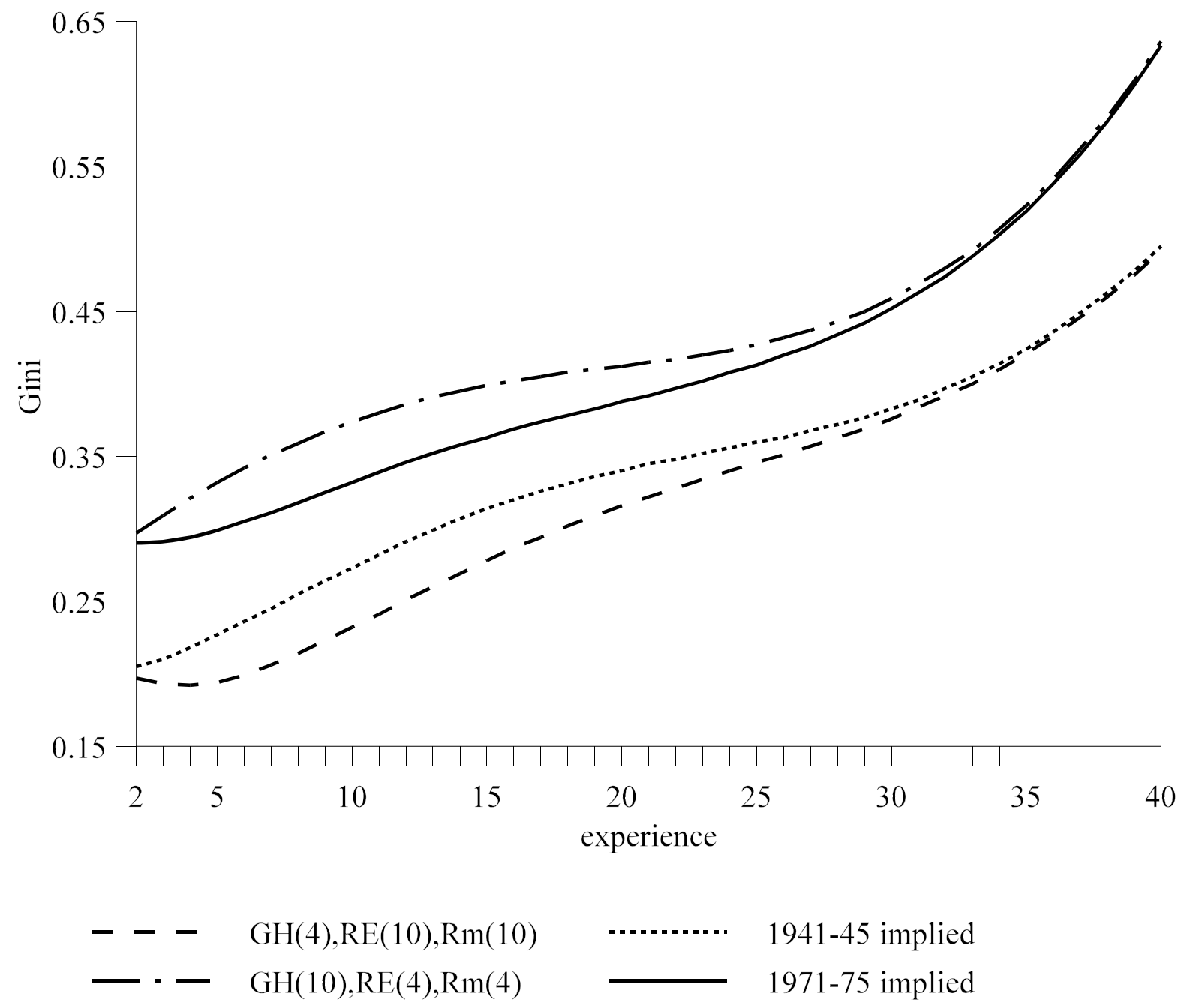

The dotted line ("1941-45 implied") plots the values implied for the Gini coefficients for the 194145 cohort from the estimates of $R_{M}=f(x, c), R_{E}=g(x, c)$, and $G_{H}=h(x, c)$ in Table 4 and the continuous line ("1971-75 implied") plots the values implied for the Gini coefficients for the 197175 cohort from the estimates of $R_{M}=f(x, c), R_{E}=g(x, c)$, and $G_{H}=h(x, c)$ in Table 4. The other two lines graph simulations of the Gini coefficients corresponding to different assumptions about husbands' earnings inequality and relative employment and relative earnings. The series denoted $G H(4), R E(10), R m(10)$ plots the values of the Gini coefficients when husbands' earnings inequality assumes its implied values for the fourth cohort and relative employment and relative earnings assume their implied values for the tenth cohort. The series denoted $G H(10), R E(4), R m(4)$ plots the values of the Gini coefficients when husbands' earnings inequality assumes its implied values for the tenth cohort and relative employment and relative earnings assume their implied values for the fourth cohort. 
Figure 10

Husbands: Values of $G_{H}, G_{H}^{e}$, and $E_{H}$ by Experience for the 1961-65 Cohort

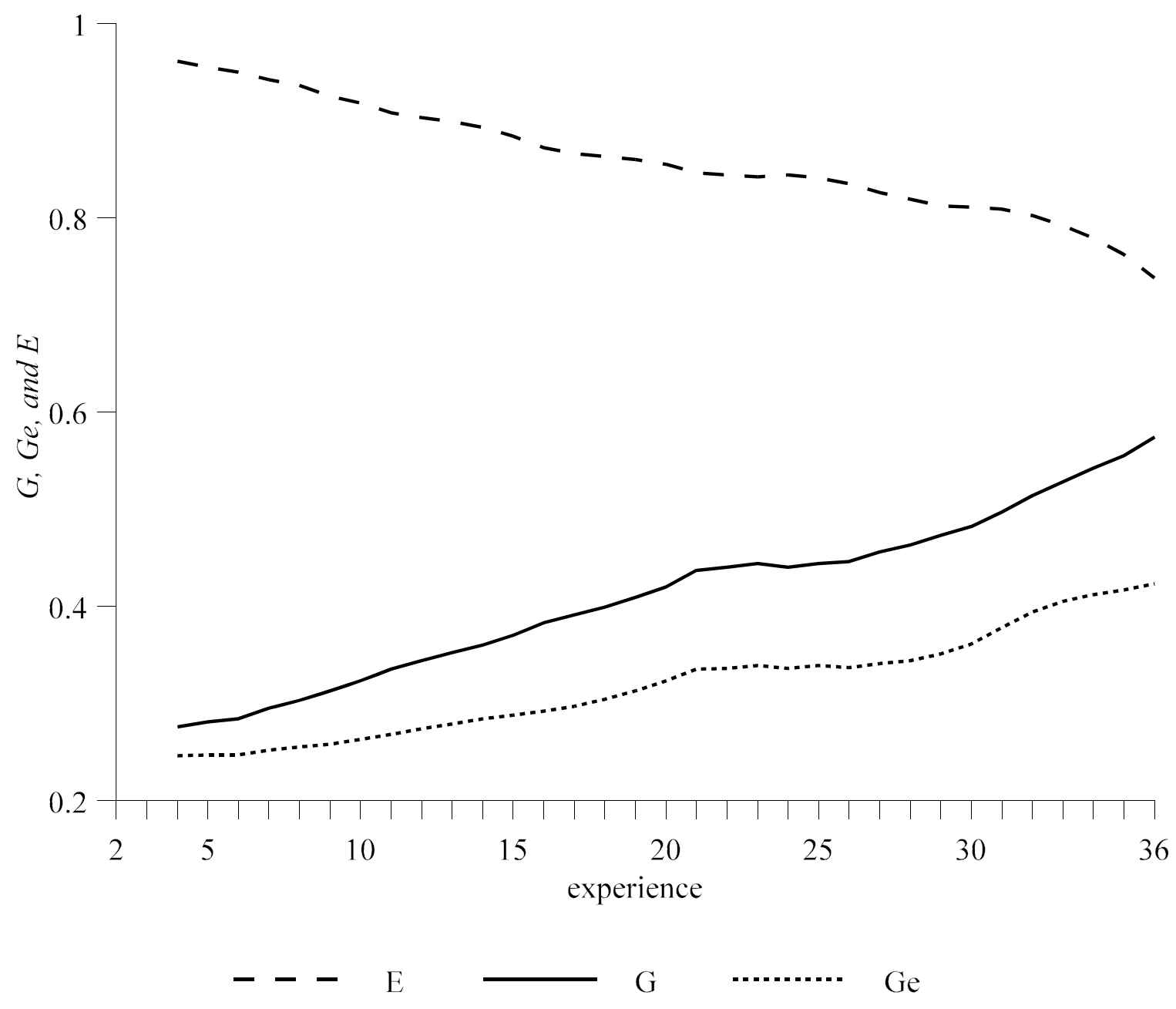


Figure 11

Wives: Values of $G_{W}, G^{e}{ }_{W}$, and $E_{W}$ by Experience for the 1961-65 Cohort

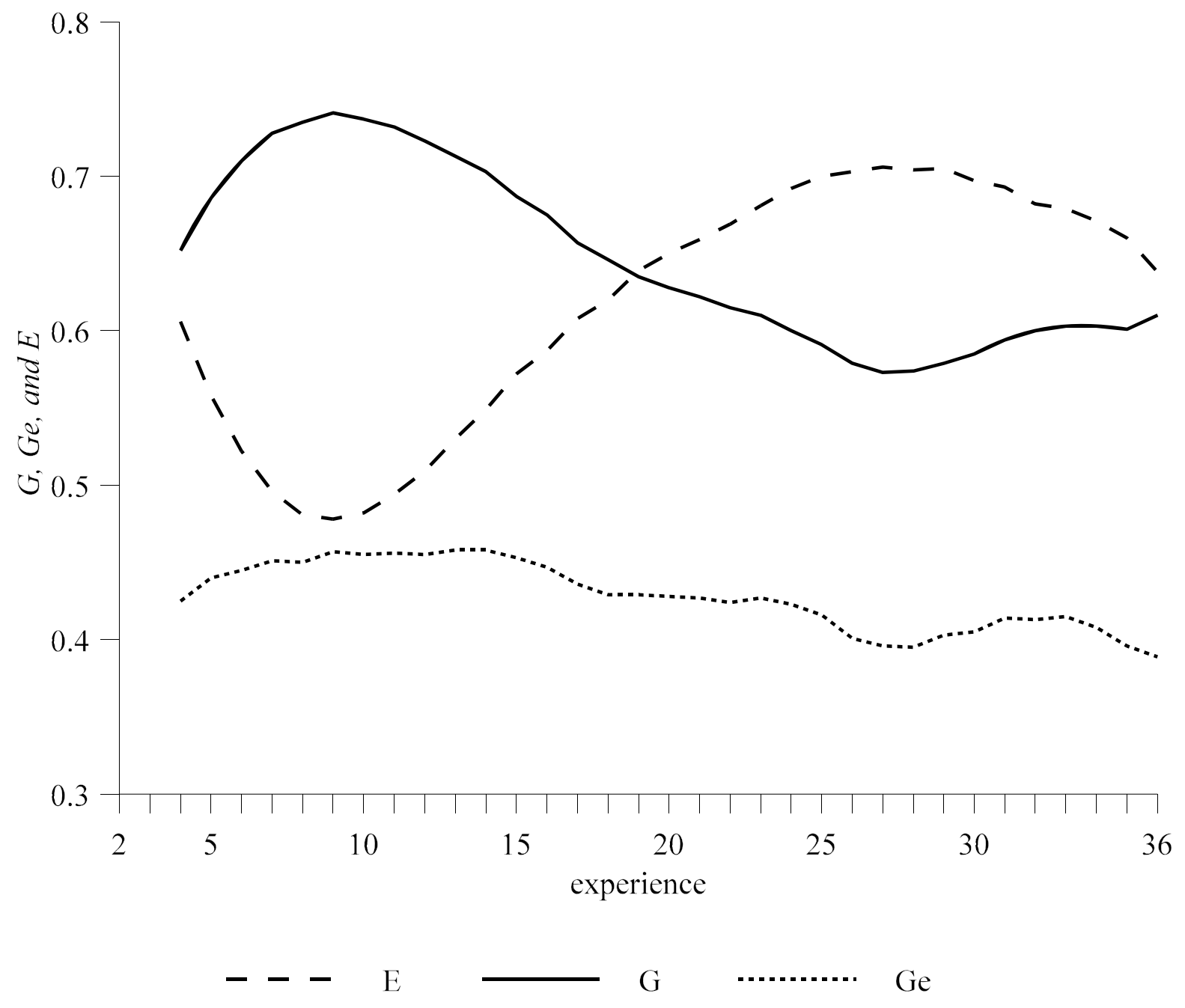


Figure 12

Values of $G$ and $G^{e}$ for Wives by Cohort for 10, 20, and 30 Years of Experience

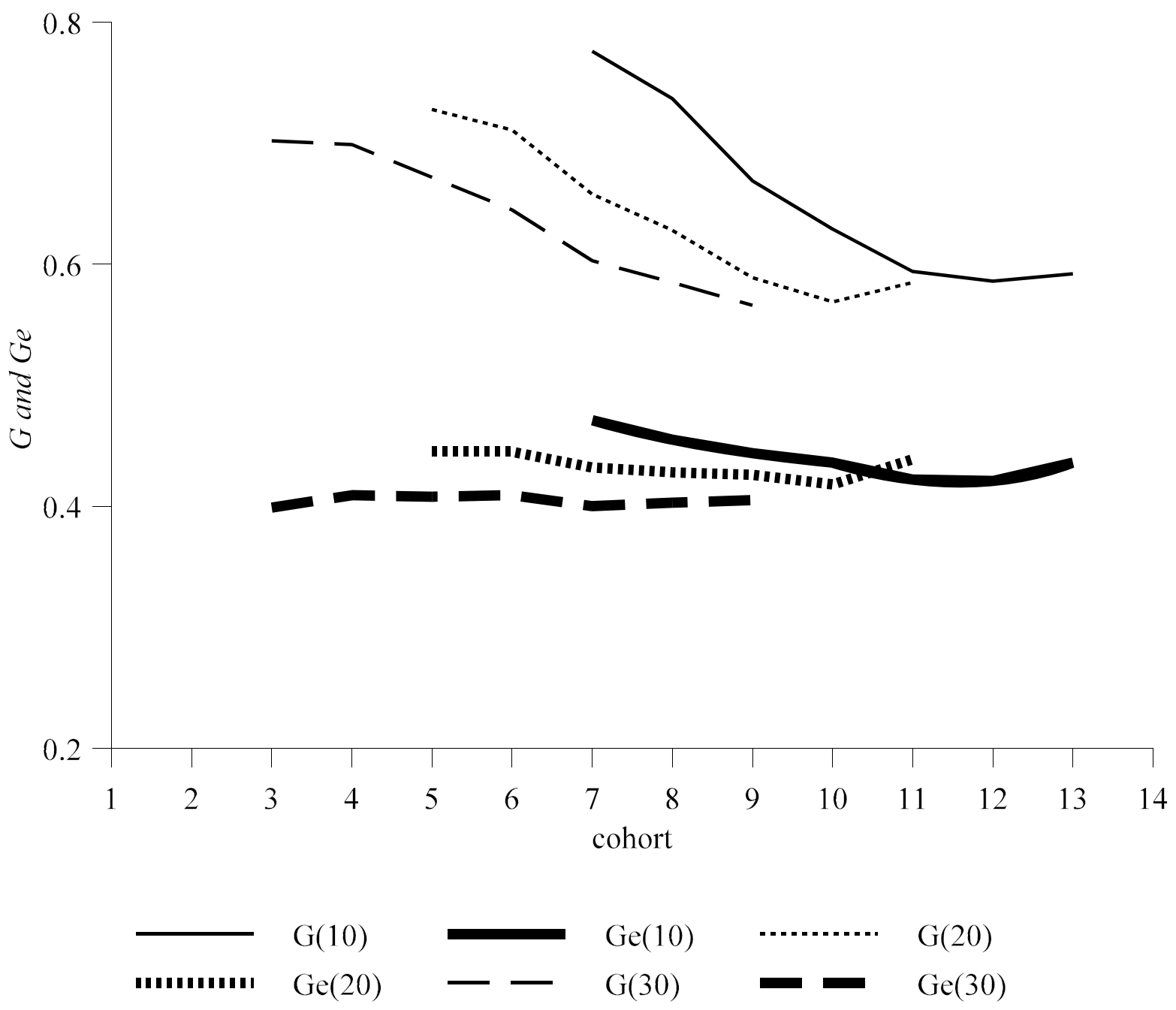


Figure 13

Values of $G^{e}$ and $G^{U}$ for Wives by Cohort for 10, 20, and 30 Years of Experience

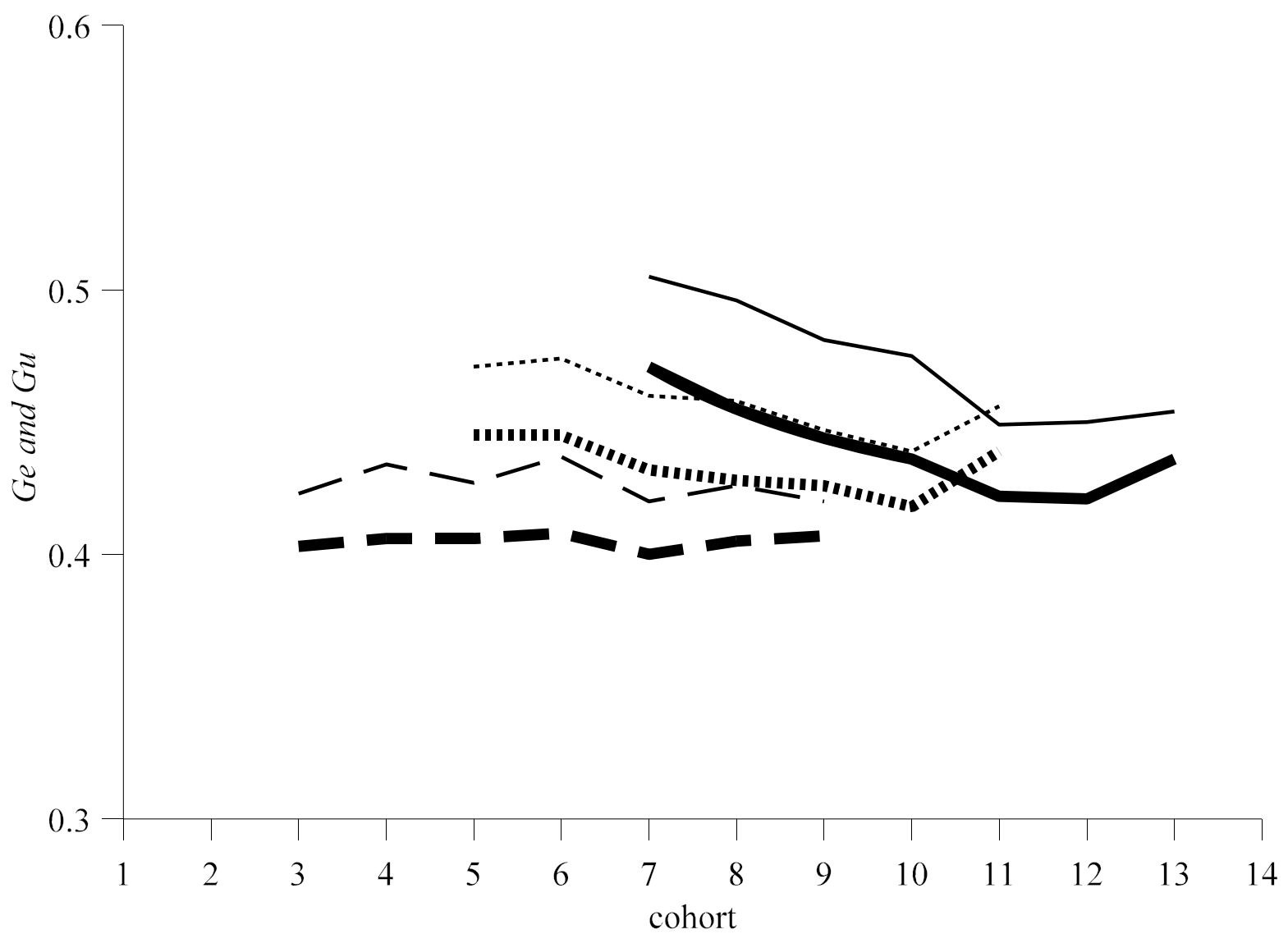

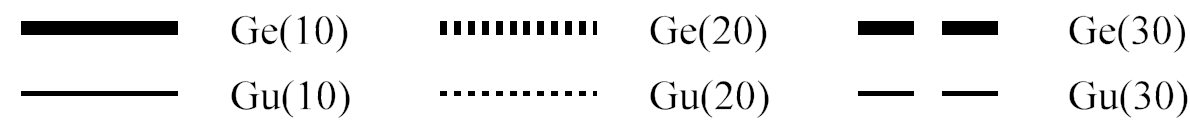


Figure 14

Estimated Cohort Trends in Median Hours Worked at Different Earnings Percentiles

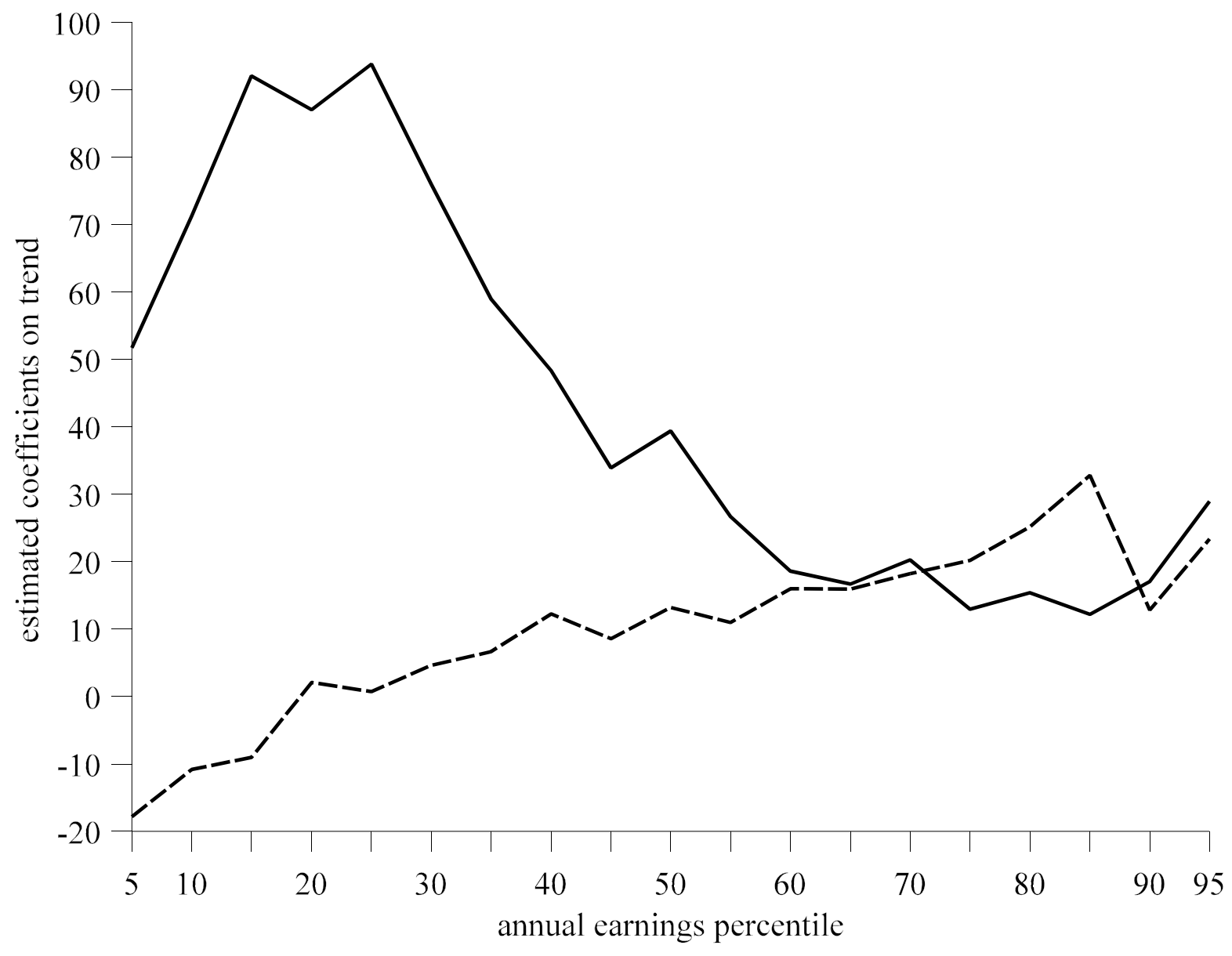

$\longrightarrow$ wives $\quad$ - - - - husbands 
Figure 15

Annual Earnings Inequality for Wives Against Years since Leaving School by the Extent of their Work Behavior

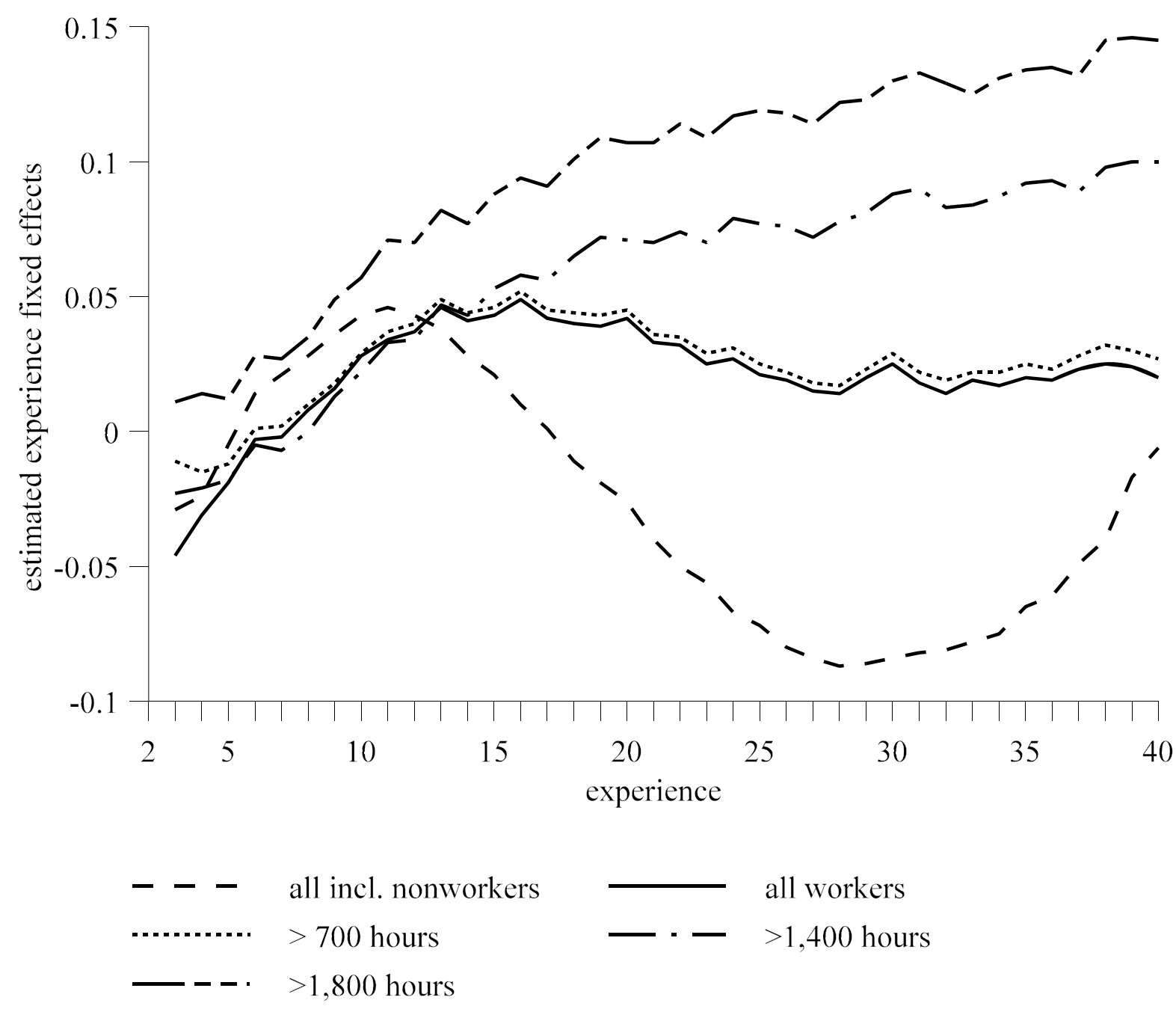

This figure graphs the estimated experience fixed effects from regression equations in which the Gini indicator of annual earnings inequality of wives is related to experience fixed effects and cohort fixed effects. The reference group is two years of experience. Five regression equations are estimated, each equation describing a different group of wives depending on their work behavior. 
Figure 16

Annual Earnings Inequality for Husbands Against Years since Leaving School by the Extent of their Work Behavior

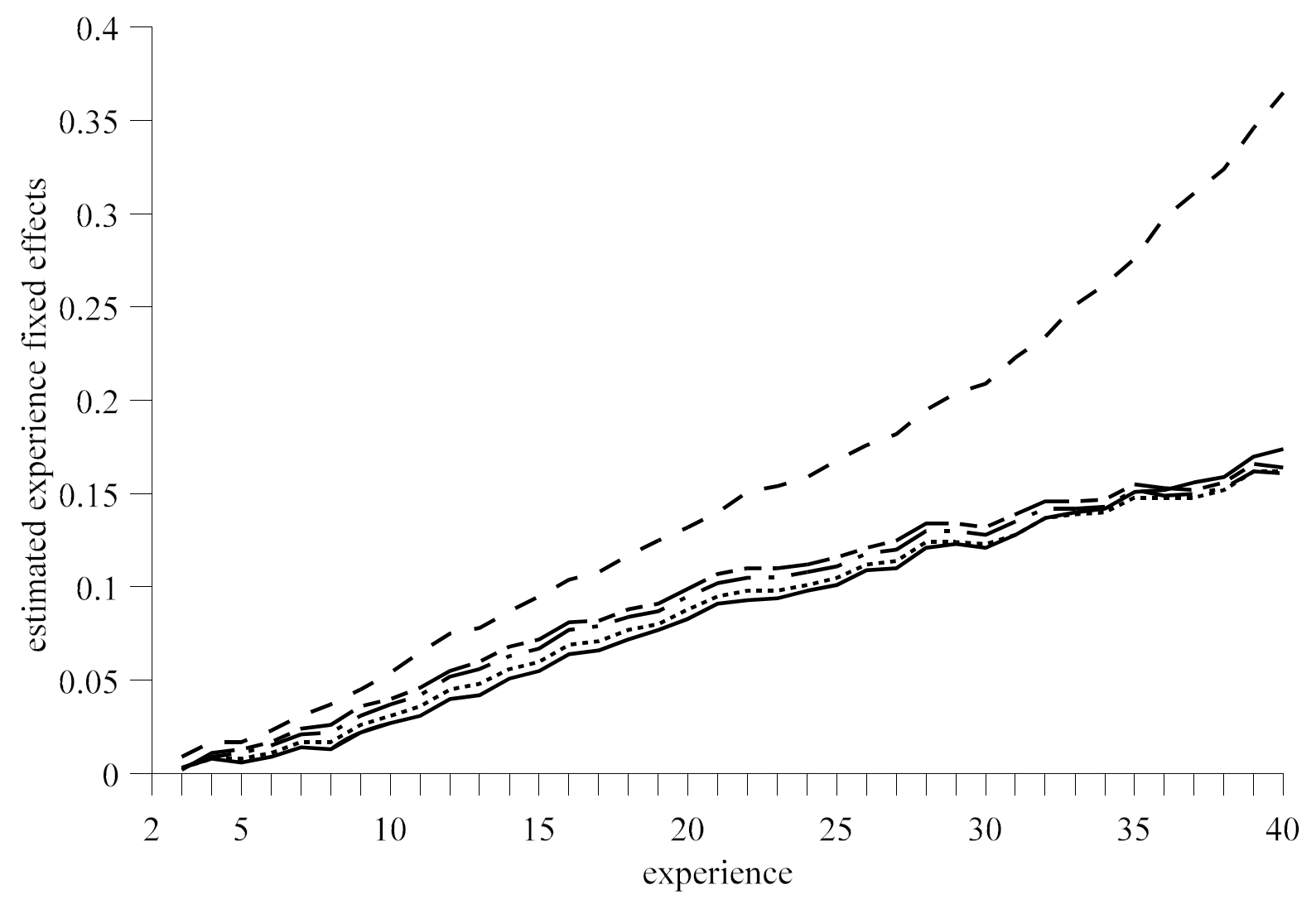

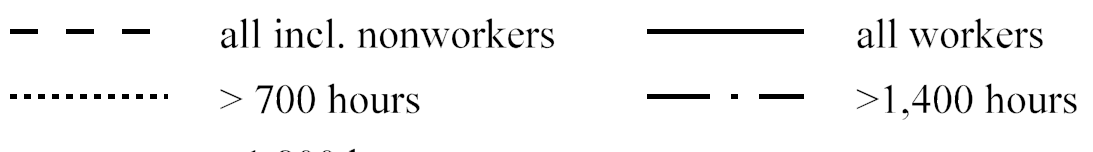

This figure graphs the estimated experience fixed effects from regression equations in which the Gini indicator of annual earnings inequality for husbands is related to experience fixed effects and cohort fixed effects. The reference group is two years of experience. Five regression equations are estimated, each equation describing a different group of husbands depending on their work behavior. 